\title{
MORPHOU BAY PREHISTORIC SURVEY PRELIMINARY REPORT: PEBBLE TOOLS FROM ORGA-KOURVELIA AND VASILIA-MOSPHILIA
}

\section{GÜZELYURT KÖRFEZI TARIHÖNCESI YÜZEY ARAŞTIRMASI ÖN RAPOR: ORGA-KOURVELIA VE VASILIA-MOSPHILIA ÇAYTAŞI ALETLERI}

\author{
Makale Bilgisi Article Info \\ Başvuru: 25 Ağustos 2021 Received: August 25, 2021 \\ Hakem Değerlendirmesi: 13 Eylül 2021 Peer Review: September 13, 2021 \\ Kabul: 19 Ekim 2021 Accepted: October 19, 2021
}

DOI : 10.22520/tubaar2021.29.009

\section{Erge YURTDAŞ * - Mehmet ÖZERENLER * *}

\begin{abstract}
This paper aims to represent an assemblage of choppers and chopping tools collected from the Morphou Bay Prehistoric Survey in Cyprus, together with their natural environment. Two new possible Early Paleolithic sites, Orga-Kourvelia and Vasilia-Mosphilia, which are very close, have been identified. In total, 13 pebble tools open the door to the possibility that the first human activity in Cyprus could be dated earlier than previously accepted and contribute to debates of hominin mobility in the Mediterranean islands from the mainland. In line with the data obtained as a result of our research, it refers to the idea that hominins may have visited the island much earlier than known, and it will be encouraging to other researchers who wish to research the Paleolithic Age in Cyprus
\end{abstract}

Keywords: Paleolithic Age, Chopper, Chopping Tool, Pebble Tools, Cyprus.

Phd. Candidate, Şht. Mustafa Orhan sokak, Korucuoğlu 3 apt. daire 5 Yenikent-Lefkoşa/Kıbrıs.

e-posta: ergeyurtdas@gmail.com

ORCID: 0000-0003-4516-8790

** Independent Researcher.

e-posta: ozerenlermehmet@gmail.com

ORCID: 0000-0003-4051-8253 


\section{ÖZET}

Bu makale, Kıbrıs’ta gerçekleştirilen, Güzelyurt Körfezi Prehistorik Yüzey Araştırması kapsamında saptanan Satır ve Kıyıcı topluluğunu doğal çevresi ile birlikte sunmayı amaçlamaktadır. Birbirine çok yakın mesafede olan Orga-Kourvelia ve Vasilia-Mosphilia adlı iki yeni olası Erken Paleolitik buluntu yeri belirlenmiştir. Bahsi geçen buluntu yerlerinde karşılaşılan 13 çaytaşı alet, Kıbrıs'taki ilk insan faaliyetinin önceden kabul edilenden daha erkene tarihlenebileceği ihtimalini işaret etmektedir. Buna ek olarak anakaradan Akdeniz adalarına gerçekleştirilen hominin hareketliliği üzerine devam eden tartışmalara katkıda bulunmaktadır. Araştırma sonucunda elde edilen veriler, homininlerin adayı bilinenden çok daha önce ziyaret etmiş olabileceği fikrine atıfta bulunurken Kıbrıs'ta Paleolitik Çăg'ı araştıracak uzmanlara katkıda bulunacaktır.

Anahtar Kelimler: Paleolitik Çağ, Satır, Kıyıcı, Çaytaşı Aletler, Kıbrıs. 


\section{INTRODUCTION}

The chipped stone assemblages that were analysed within the scope of this article could refer to the earliest known human activity in Cyprus so far. Excluding the Lomekwian industry, which is observed only in Kenya, western Turkana region, Lomekwi 3 site (Harmand et al., 2015), Oldowan type pebble tools, which spread out of Africa and are seen in most parts of the world such as Europe and Asia (Carbonell: 2009: 29; Braun \& Hovers: $4 ;)$, point to the first standard tool technology produced by the genus Homo. This technology was discovered during the survey carried out in Morphou Bay and its surroundings in Cyprus. With the discoveries mentioned above, the prehistory of Cyprus could be dated much earlier than known. The earliest date of the Oldowan techno-cultural complex has been delimited as 2,616,897 and 2,644,446 Ma, with current studies (Key et al., 2021: 4), and also it could be dated approximately to 2.6-1.6 $\mathrm{Ma}$ in Africa, 1.8-0.6 Ma in Europe and 2.0-0.8 Ma in Asia (Barsky, 2009: 40, Fig. 4.1).

Although in some cases, Oldowan type pebble tools are identified within the context of Middle Paleolithic technologies, it should be remarked that this depends on the characteristic of the material group and its geological context (See. Dinçer, 2016a: 52). If artefacts are recovered from stratigraphic deposits dated to the Middle Paleolithic, Late Lower Paleolithic, or another later chronological time span or collected with different materials that clearly belong to distinctive cultural periods, they had better be considered part of the technological element of the chaine opératoire (operational sequence) of them. When considering Paleolithic technology from a holistic perspective, it is not surprising that the technique and production models that characterize specific cultural phases might be seen in the successive periods that follow them (See. Bar-Yosef \& BelferCohen, 2001: 21). This technological continuity could be associated with the learned behavioural traditions of various human species that existed during the Paleolithic Age. As a result, chipped stone technologies evolved and developed over time due to the knowledge of techniques and skills learned from the ancestors. Acheulo-Yabrudian assemblages in the Levant, define the end of the Lower Paleolithic and the beginning of the Middle Paleolithic and reflect three different technological traditions such as Acheulian, Yabrudian and Amudian, are among the best examples of technological continuity (See. Shea, 2013a: 76-77). Further, early Ahmerian assemblages were defined as Initial Upper Paleolithic, where El-Wad points, Ksar Akil points, and prismatic blade production were dominant, but also Levallois technique continued, it could be shown as another example (See. Shea, 2013a: 152). Consequently, it cannot be denied that technological continuity is a critical phenomenon in the Paleolithic studies, on the other hand, it would be appropriate to emphasize that Pebble Tool technology is conspicuously representative of chipped stone technology of the Lower Paleolithic Period in the many regions, at least our knowledge so far. (See. Dinçer \& Türkcan, 2011: 5). Even though there are no absolute dating studies in our research and no fossil remains have been recovered, chipped stone materials techno-typologically coincide with the above-mentioned cultural phases in the regions of the world. It indicates that Cyprus might be visited by hominins at such an early time in the Lower or Middle Paleolithic Period is remarkably important; it is also thought to change the views in Paleolithic research and cause new debates and also develops the interest of other researchers in studies of the Paleolithic Age.

With the acceleration of paleoanthropological research in recent years, the ongoing debates about where and when the genus Homo emerged are also up-to-date (Hanke, 2015). Two different hypotheses explain the emergence of the genus Homo and its spread to the world. The most accepted is "out of Africa", and the other is the "multiregional" hypothesis (Klein, 2008; Scerri et al., 2019). Many scholars who supported the "multi-regional" hypothesis argued that the Paleoanthropological and Palaeolithic remains in Yuanmou and Nihewan in China, Dmanisi in Georgia and Atapuerca in Spain are undeniably significant and should not be neglected (Wolpoff et al. al., 2000: 133; Lordkipanidze et al., 2007; Carbonell et al., 2008, 465; Mgeladze et al., 2011). It is understood from Dmanisi in Georgia that the earliest residue of the genus Homo outside of Africa is 1.8 million years ago (Gabunia et al., 2000: 785, Lordkipanidze et al., 2007). Despite all this, it is known that the earliest members of the genus Homo lived in Kenya about 3.3 million years ago (Harmand et al., 2015). With the studies above, when the genus Homo emerged and which routes they took while spreading around the world, whether it was "Out of Africa" or "Multiregional", whether they overcame the sea barrier, is still a matter of debate. According to the data obtained from the studies carried out in this field, people had been out of Africa not just once but gradually more than once (Templeton, 2007: 1507; Dinçer, 2016b: 213).

Consequently, it is claimed that the first wave of immigration from Africa occurred 1.9 million years ago, the second wave was 650 thousand years ago and finally, the third wave was 130 thousand years ago (Relethford, 2008: 558). The aforementioned non-African expansions are also temporally related to fossil remains. The first wave distribution corresponds to the emergence and spread of H. Erectus, the second to the spread of $\mathrm{H}$. Heidelbergensis, and the third to the emergence 
and spread of H. Sapiens (Templeton, 2007: 1508). Although this data is presented as a result of reassuring analysis, they should be considered suggestive rather than definitive. When considering that Cyprus is an island isolated from the surrounding mainland by the sea and that it has never had a natural land bridge with the mainland throughout its geological history, if the fossils or cultural materials will be recovered from the stratigraphical layers in the island, in the future, much of things could be changed what we know about the cultural and cognitive evolution process of the genus Homo. It could also make significant contributions to Paleoanthropology and Paleolithic Archeology and to being able to change many hypotheses or build news. Our finds are pretty important in order to contribute to the idea of the possibility of "Early Paleolithic Cultures" in Cyprus.

\section{RESEARCH DESIGN AND METHODOLOGY}

Cyprus has been at the centre of attention for centuries and has been inhabited by various communities from prehistoric times to the present. Although we have data that the island hosted different groups in prehistoric times, our knowledge of these people's lifestyles is limited. In this context, an archaeological survey was carried out in the northwest of the island, in Morphou Bay and its surroundings, to reach new data that could support the cultures of the prehistoric times of Cyprus. The research named "Morphou Bay Prehistoric Survey" aims to examine the northwestern part of Cyprus, which is not apprehended much in terms of Prehistory. This research also intends to investigate the hunter-gatherer groups and the agriculturalist-farmer communities, including their distribution on the island, with new data. In the northwestern part of the island, the survey was carried out in two different regions: Lefka and Kyrenia districts. This study was primarily conducted in Ambelikou Village located in the west of Morphou Bay; Vasilia, Orga, Kormakiti and Liveras Villages located in the northeast of the bay and also the west end of the Kyrenia coastline. During the first season of the survey, previously discovered settlements were revisited, materials collected, and new sites were identified and documented. In this article, only Paleolithic artefacts analysed belong to Orga and Vasilia; the Neolithic and Chalcolithic data collected from the survey will not be included.

Various survey methods were preferred by the geography and carried out in the region showing mountainous and coastal features from the northwest slopes of Kyrenia Mountains to the Kormakiti Cape. According to the multidisciplinary nature of the Morphou Bay Prehistoric Survey, both earth sciences and archaeological methods were used during the fieldwork. In this type of study, geological maps, topographic data and satellite images needed to follow the process. This type of interdisciplinary research requires methodological flexibility according to conditions during fieldwork. In the first stage of the research, two main objectives were determined. The first objective is to reconcile the dynamic geological structure of the research area with early human activities and to determine its potential and, the second is to identify the site locations and collect the materials. In addition, due to the geological structure and geomorphological formation, it is necessary to associate the region with mountainous and coastal morphology with the archaeological process. It is a guide to identify areas with archaeological potential for more intensive and systematic research in future.

Topography and slope maps were studied before starting the research. GPS was used since the team could determine its position according to satellite maps and locate the finds collected from the surface. The survey was carried out by fieldwalking with three archaeologists at intervals of one meter until the density of finds was encountered. When an increase in density of finds was observed, a more detailed survey was carried out by narrowing the rows or applying a grid system. GPS is the essential tool
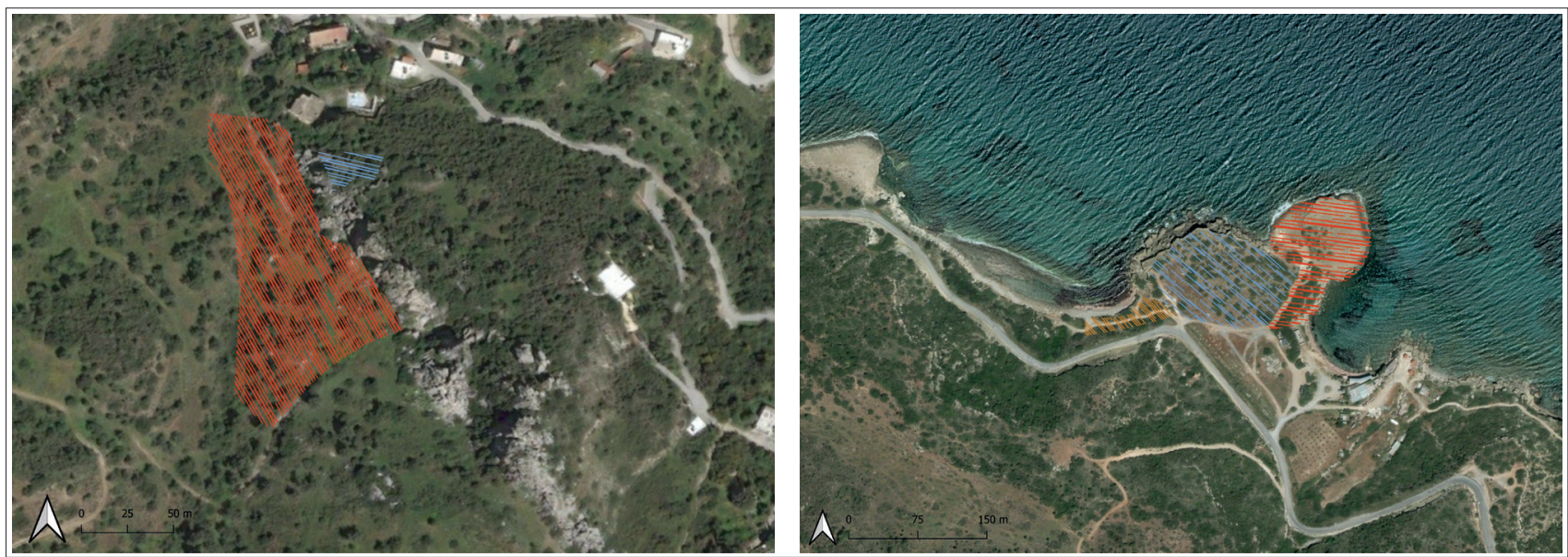

Figure 1: Field walking and GPS tracking on Orga-Kourvelia and Vasilia-Mosphilia. / Orga-Kourvelia ve Vasilia-Mosphilia'daki yüzey araștırması metodu ve GPS kayıtları. 


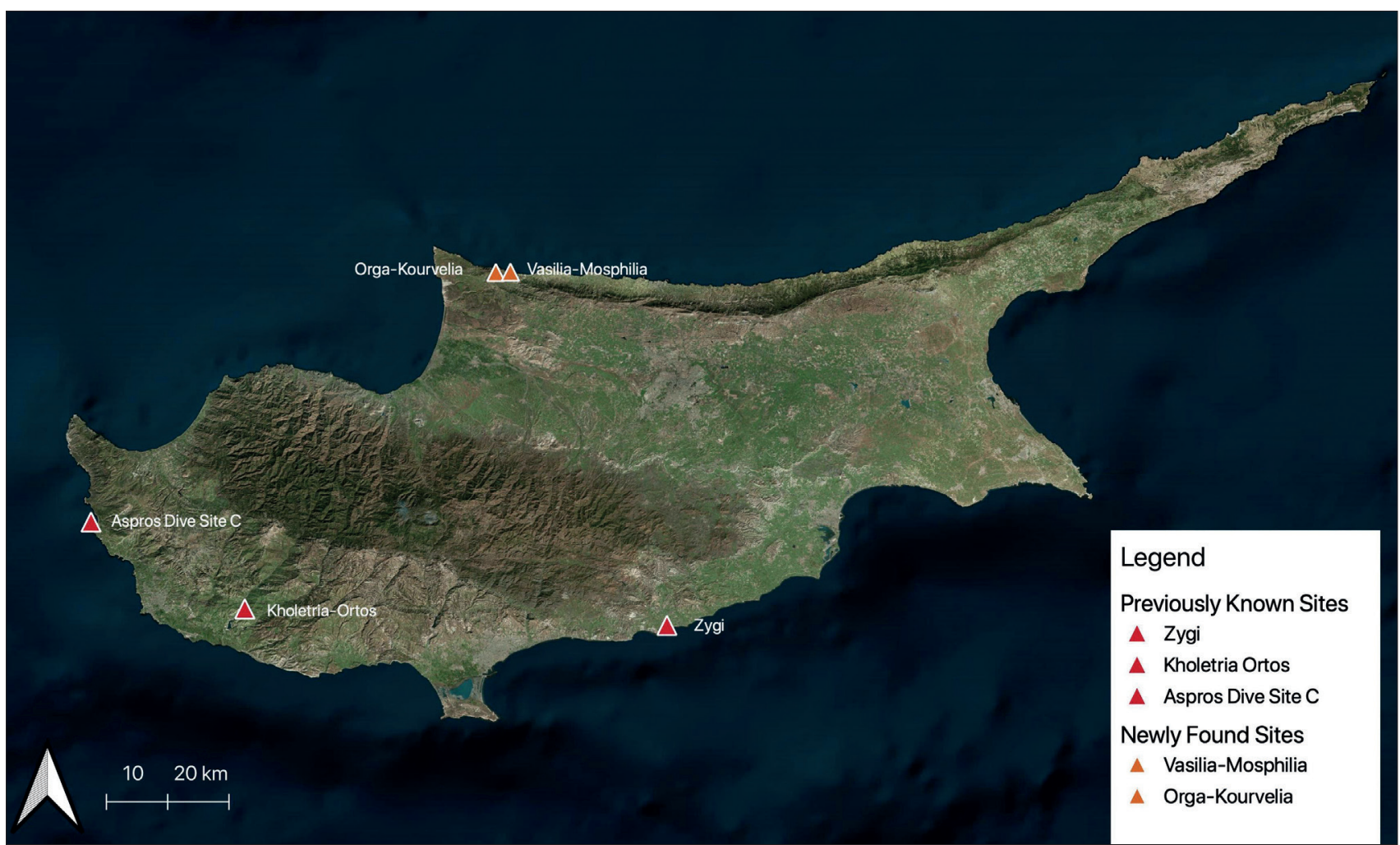

Figure 2: Previously known possible Paleolithic Sites and new-found sites. / Önceden bilinen olası Paleolitik buluntu yerleri ve yeni saptanan buluntu yerleri.

for all research based on contemporary methods, in this research GPS tracking and waypoints to record were used, where Paleolithic finds were detected. Even if it's singular, every find encountered in the field has been recorded and marked as a find location. Individual finds also contribute with the idea that somehow past human activities might indicate that they could spread over large areas. The areas where collective or scattered finds, which could be related to each other, are categorized as campsites/workshops according to the conditions and material groups.

\section{RESEARCH BACKGROUND}

Studies on the Paleolithic Age in Cyprus have remained considerably insufficient. The evidence on the island that can be dated to the Paleolithic Age has always been approached as questionable and negative, in line with the doctrine that the early humans could not cross the sea barrier. The first data on the island could be identified as Paleolithic, consisting of a few flint artefacts discovered in the Zygi Valley by C. Vita-Finzi during a visit to the island in 1968 (Vita-Finzi, 1973: 453). Shortly afterwards, E. D. Stockton found several pre-Neolithic finds in his research carried out in the north of the Kyrenia Mountains, in the coastal and upland regions. One of the artefacts is a "heavily patinated biface tool, roughly chopper-like", as Stockton defined. In addition, the Upper Paleolithic and Mesolithic Period standard technology are also introduced (Stockton, 1968: 18,19). Another Paleolithic discovery is the Acheulean handaxe discovered by S. Swiny near the Neolithic settlement Kholetria-Ortos (Strasser et al., 2016). The suggested handaxe was later re-evaluated by A. Simmons, who excavated Kholetria-Orthos, indicating that the Neolithic picks in the settlement resemble bifaces from the early Paleolithic Period. However, Kholetria-Ortos's data shows that the bifacial tool is morphologically and techno-typologically different from Neolithic picks and is a typical Paleolithic handaxe (Strasser et al., 2016). The first systematic excavation carried out within Paleolithic research in Cyprus is the Aspros Dive Site C, excavated in 2007 under the scientific consultancy of A. J. Ammerman. Aspros site A is dated to the Final Paleolithic and Epi-Palaeolithic, while the submerged site $\mathrm{C}$ dated to the Final Paleolithic (Ammerman, 2020) (Figure 2) ${ }^{1}$. Eventually, in 2015, a survey was conducted under the direction of C. M. Erek to investigate Paleolithic Age cultures in the north of Cyprus. The many remarkable materials were collected by Erek point to the Middle Paleolithic Period. Although there is no published article to describe a comprehensive techno-typological analysis of the assemblages, information about the survey and material group could be acquired from poster study which was presented by Alper Basiran and Cevdet Merih Erek. ${ }^{2}$

\footnotetext{
Orga-Kourvelia $\left(35.356645^{\circ} 33.031512^{\circ}\right)$ - Vasilia-Mosphilia $\left(35.356850^{\circ} 33.056253^{\circ}\right)$

2 It was presented at the "Society for American Archaeology $81^{\text {th }}$
} 


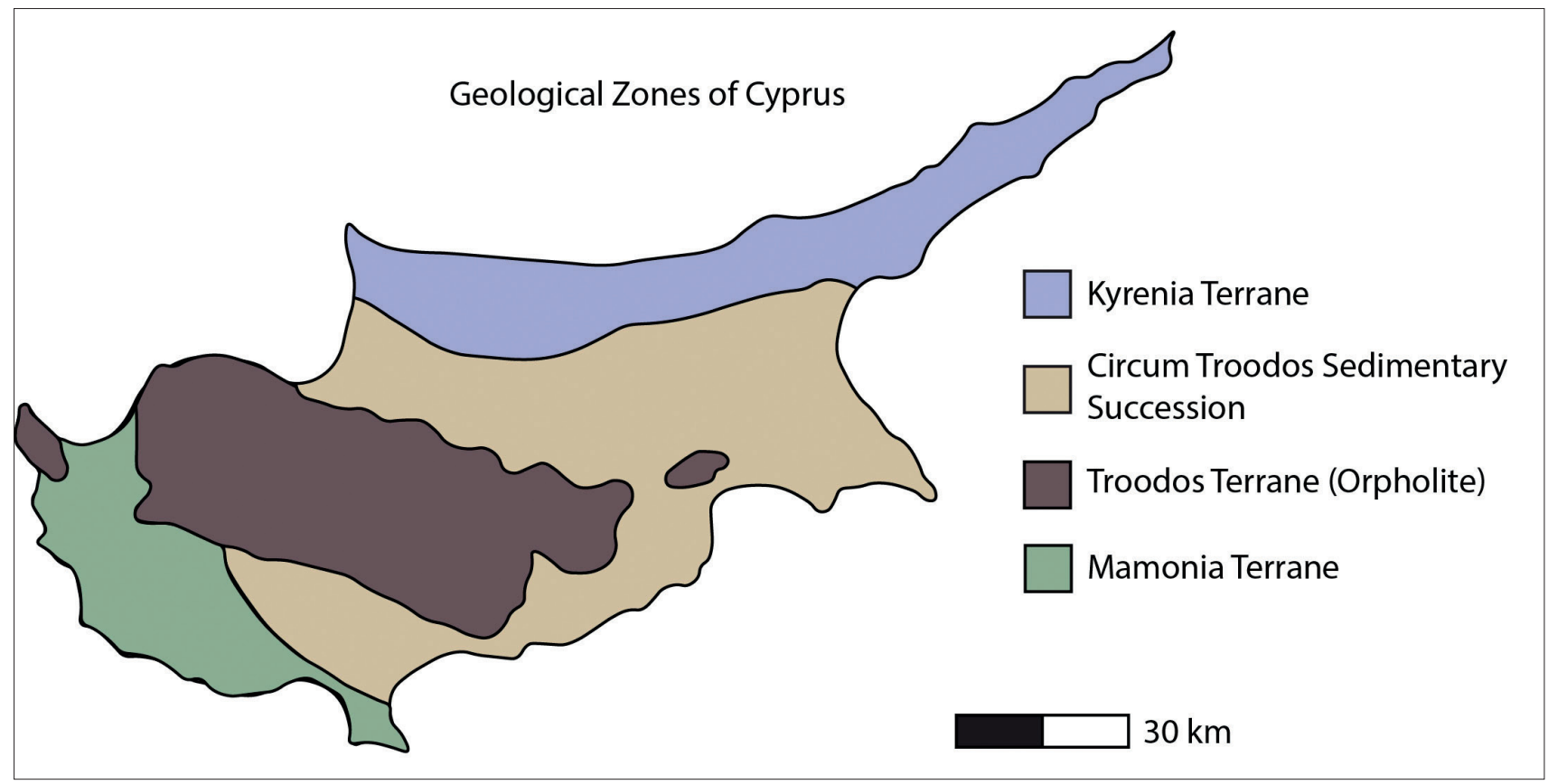

Figure 3: Geological Zones of Cyprus (reproduced from Geological Survey Department of Cyprus) / Kıbrıs'ın Jeolojik Bölgeleri (Kıbrıs Jeolojik Araştırma Departmanından alınmıştır).

Nevertheless, not much research has been carried out until today to reveal the early stages of the Paleolithic Age on the islands of the Mediterranean. Following the data put forward by the researchers, there is still skepticism due to the lack of sufficient systematic excavation. However, there is various discussion in the scientific community about the existence of the Paleolithic Age in Cyprus (Knapp, 2010).

\section{BRIEF DESCRIPTION OF THE GEOGRAPHY}

Cyprus is an island located in the easternmost part of the Mediterranean Sea, which is a remnant of the Tethys Ocean, formed by the fragmentation of the supercontinent Pangea about 250 million years ago. The Tethys Ocean was destroyed due to the collision of African and European tectonic plates about 30 million years ago, and then small inland seas remained from this ocean (Cavazza \& Wezel, 2003: 163-164).

The Mediterranean Sea forms the westernmost part of the Alpine-Himalayan orogenic belt extending from Spain to New Zealand (Mather, 2009: 5). The west coast of the Arabian plate in the east, the south coast of the Anatolian plate in the north, the Strait of Gibraltar in the west and the northern shores of the African plate in the south are the natural boundaries surrounding the Mediterranean. This situation caused the Mediterranean basin to be separated

Annual Meeting in Orlando, Florida, in 2016". https://www. saa.org/annual-meeting/programs/program-archives https://www.academia.edu/27972133/The_Prehistoric Cultures_in_the_Turkish_Republic_of_Northern_Cyprus from other geographies as an isolated region. Although it has its unique climate, fauna, flora and geomorphology; geologists prefer to study the Mediterranean Sea by dividing it into three different regions as western, central and eastern (Çiner et al., 2019: 1; Mather, 2009: 6; Lort, 1977: 152, 169, 180). Upon evaluation, it would be the correct approach to consider Cyprus geographically by limiting it to the Eastern Mediterranean region.

Topographically, it is possible to express that Cyprus consists of four different structures (Galili et al., 2015: 181), (Figure 3) $)^{3}$. The Troodos Terrane (Orpholite) cover the south and central part of the island, The Mamonia Terrane in the southwest region, the Kyrenia Terrane running parallel to the northern coasts, and Circum Troodos Sedimentary Succession (The Mesaoria Plain) ranges between the Morphou and Famagusta Bays and separates these two mountain masses. The formation of these geological structures depends on tectonism (Robertson \& Xenophontos, 1993: 85-88). The island was shaped by the collision of the European and African plates. Kutoğlu (2010: 12-14) explains the geological structures formed by the collision of two tectonic plates. Firstly, the Troodos volcanic mass reflects lithological features consisting of Triassic-Upper Cretaceous igneous rocks and surrounded by Upper Cretaceous-Late Miocene chalks. Secondly, Mamonia Complex has volcanosedimentary features ranging from the Middle Triassic to the Upper Cretaceous. Finally, geosynclines rose and

\footnotetext{
http://www.moa.gov.cy/moa/gsd/gsd.nsf/0/ F9B6C7484AFDCADCC2258363003BE7C5/ thumbnail/0.84?OpenElement (Accessed on may 2021)
} 
formed the Kyrenia Terrane. The Kyrenia Mountains consist of Jurassic-Upper Cretaceous aged rocks, and Oligo-Miocene turbiditic rocks identify their surroundings. The area between these two mountain masses formed the collapse basin with faulting, and then the Mesaoria Plain filled with alluviums as a result of the transport and accumulation of dynamic processes. Mesaoria Plain consists mainly of PlioQuaternary sediments.

Regarding the tectonic activity of the region, it has been noted that the geography where Cyprus is located is quite active. As a result of the geological research carried out on the island, it is known that there are many faults such as reverse, lateral strikeslip, normal and thrust (Kinnard, 2011, Fig.1), as well as the presence of two primary marine-based fault lines passing through the northern and southern ends of Cyprus (Palamakumbura \& Robertson, 2016: Fig.1a). The marine-based fault line in the north is a continuation of the "East Anatolian Fault Line", which is very active in the Anatolian Plateau. This fault line dives into the sea from the Iskenderun Bay and then continues along the Kyrenia Mountains, then once again dives from Morphou Bay to the Bay of Antalya, in Turkey. Another marine-based fault line located at the southern end of the island forms the collision boundary of the African Plate and the Anatolian Plate, also named "Cyprus Arc" (Palamakambura et al., 2016, Fig.1). From the Late Cretaceous, the lower block of the Mediterranean moves down to Anatolia, forming a subduction zone in this area; Cyprus is also located on this subduction zone and is affected by tectonic movements. (Kutoğlu, 2010: 37).

\section{RESEARCH AREA}

In the first stage of the Morphou Bay Prehistoric Survey, the fieldwork was carried out in the coastal and mountainous area northwest of the island, from Vasilia to The Cape Kormakiti (Figure 4). The region is geographically steep and rocky and also suitable for human habitation. Based on this, narrow valleys that continue from the mountain to the sea, as well as high plains and streams that have dried up today, are remarkable. There are Orga Mountains, which is the western end of the Kyrenia Mountains, extending from the Panagra Pass to the east towards the Kormakiti Cape, and consists of hills below 300 meters. This mountain range is about $6 \mathrm{~km}$ long and its highest point is 343 meters. The Orga mountain mass, which loses its height as it continues towards the west, leaves its place in the coastal plains and reaches the sea with cliffs (Ilkseven, 2021, 37).

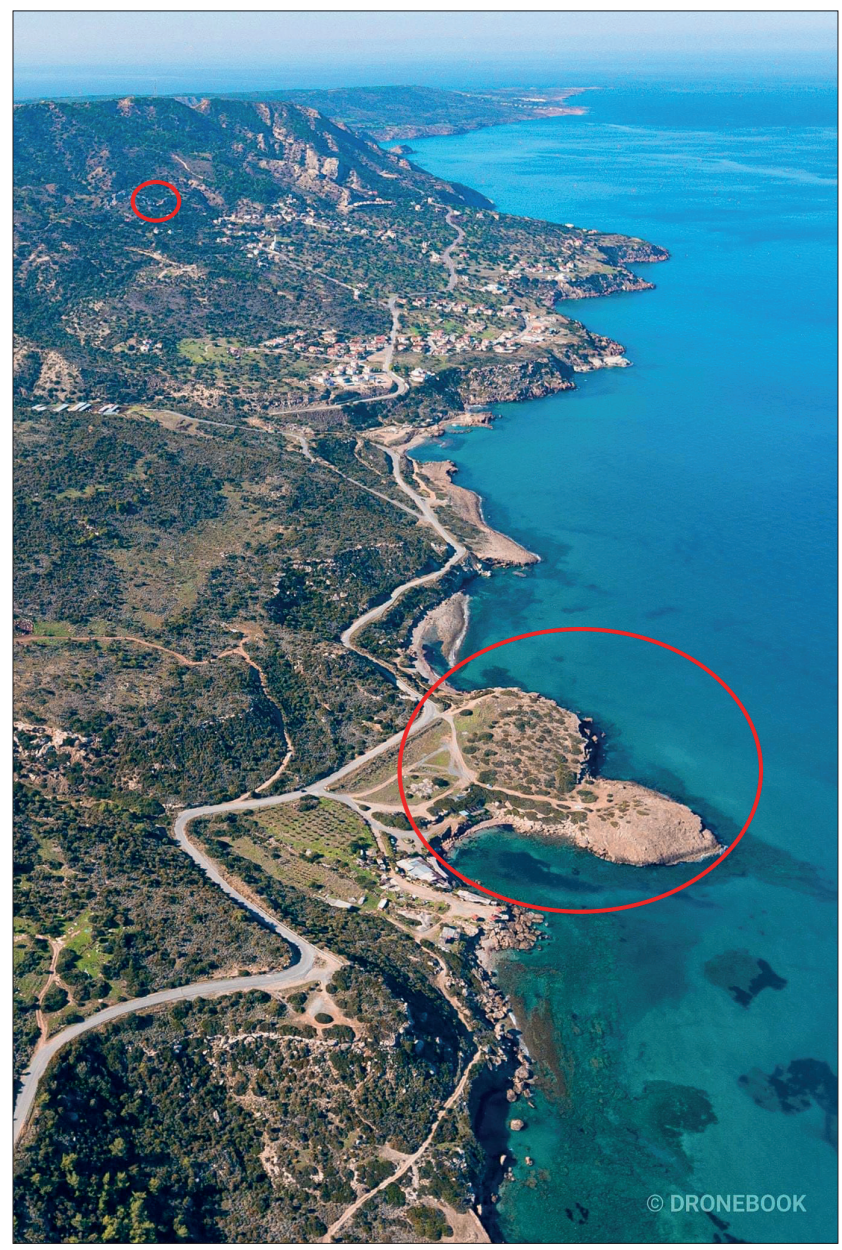

Figure 4: The aerial view of the research area and the sites of Orga-Kourvelia and Vasilia-Mosphilia (Photo by: Ali Y1lmaz). / Araştırma alanı ve Orga-Kourvelia ile Vasilia-Mosphilia buluntu yerlerinin havadan görünümü (Fotoğraf: Ali Yllmaz).

During the 2020 field season of the Morphou Bay Prehistoric Survey, two sites were found that could be associated with the Lower/Middle Paleolithic Period. One of the sites is located within a mountainous, relatively high area in the village of Orga; and the other is located on the coast within the borders of Vasilia, very close to the beach. The air distance between the two sites is $2.5 \mathrm{~km}$. The site located within the boundaries of Orga is $140 \mathrm{~m}$ above sea level and located in a relatively lowlying area with less slope where the higher parts of the mountains decrease; at the same time, it is in a sheltered area in the valley, just west of the massive rock block known as "Kissing Rocks" (Figure 5, 6). The place is named Orga-Kourvelia using the village's name and the locality, in line with the naming system used in Cypriot archaeology for several years. 


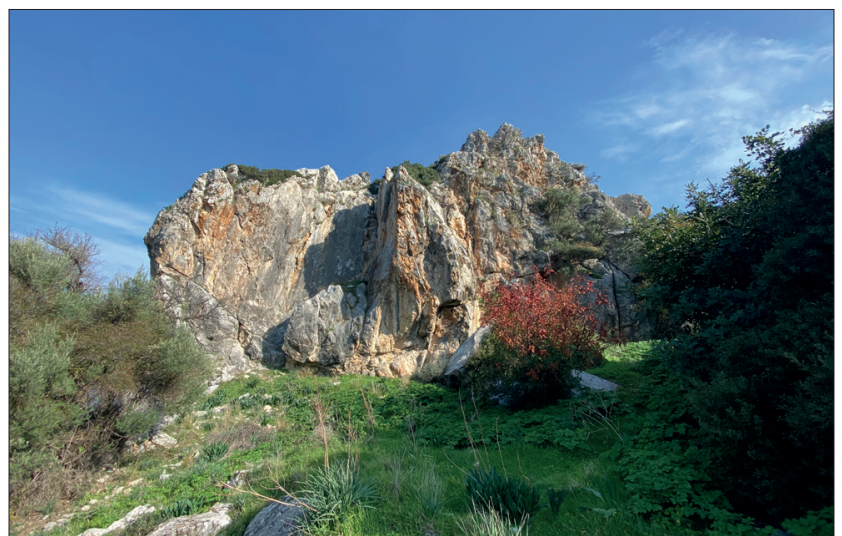

Figure 5: The view of Orga-Kourvelia from the southwest. / OrgaKourvelia'nın güneybatıdan görünüşü.

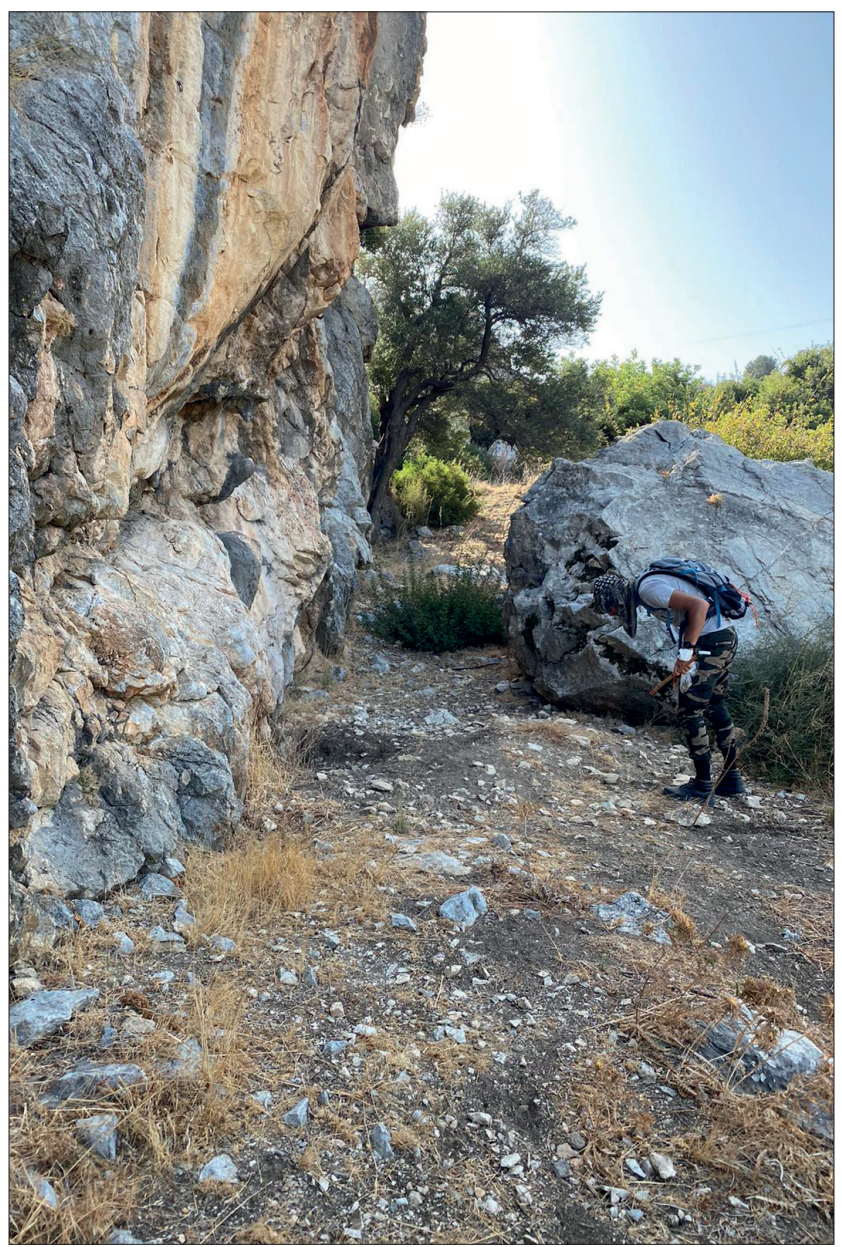

Figure 6: The view of Orga-Kourvelia from the west. / OrgaKourvelia'nın batıdan görünümü.

Another site is in the village of Vasilia: on the shore, at a low altitude of about 6-10 m above sea level. The site, called Vasilia-Mosphilia, is in a region where the Orga Mountains reach the sea with cliffs. The mentioned geography is where both Pleistocene sandstones and transported deposits are seen (Figure 7,8). The assemblages were collected in two different areas from Vasilia-Mosphilia. The first is the area where the Middle Paleolithic materials were collected over the sandstones.
Another area, where Pebble Tool technology is observed, which is the main subject of the article. These assemblages, which represent the Pebble Tool technology, might have been transported and accumulated by rivers or, on the other hand, it could be taken as part of the Middle Paleolithic technology. At this point, it is impossible to determine whether Vasilia-Mosphilia pebble tools belong to the Lower or Middle Paleolithic period. In order to be argued such as thing, either should be made an absolute dating of the geological area where they were found or should be carried out an archaeological excavation on the sandstones where the Middle Paleolithic artefacts were recovered to reveal the distribution of the materials. So this is the primary reason why we hesitate to associate Vasilia-Mosphilia's pebble tools with the Lower Paleolithic period. The second reason is that they are morphologically and techno-typologically different from the Orga-Kourvelia samples, which are typical Oldowantype chopping tools, as will be explained in detail in the next section.

The Pleistocene sandstones were frequently observed along the Vasilia-Liveras coastline. During the survey, mollusks/seashells were observed in these sandstone structures. Right behind Vasilia-Mosphilia, it is possible to recognize marine terraces indicating sea-level changes that can be dated to the Pleistocene or possibly earlier epochs (Figure 9). Studies conducted on this subject have enabled the Pleistocene terraces, along the island's northern coastline, to be identified and dated (Galili et al., 2015; Palamakumbura et al., 2016). However, in the same region, it is possible to see wave notches on the sandstone areas above the current shoreline - these notches are considered significant geological formations that point to the sea level changes precisely. As understood from observations made in the region during research, Cyprus uplifted and subsided many times due to tectonic activities in geological eras. The coastal lines have been constantly changed by the movement of eustatic and isostatic adjustment.

The data obtained from the research on the sea-level changes in the Quaternary have an essential position in understanding the Paleolithic Age of Cyprus and evaluating its relations with its environment. The main reason for this is that the natural environment and geomorphology are primarily effective when evaluating how the genus Homo might have arrived in Cyprus in the Paleolithic Age. The closest distance of Cyprus to the mainland today is $65-70 \mathrm{~km}$. Although the current coastlines took their present appearance around $7000 \mathrm{BC}$, it is known that the coastlines in the Paleolithic Age are pretty different from today on a global scale (Benjamin et al., 2017, Fig. 4, Fig. 7). "Marine Oxygen Isotope" studies clearly show that the climate and sea levels in 

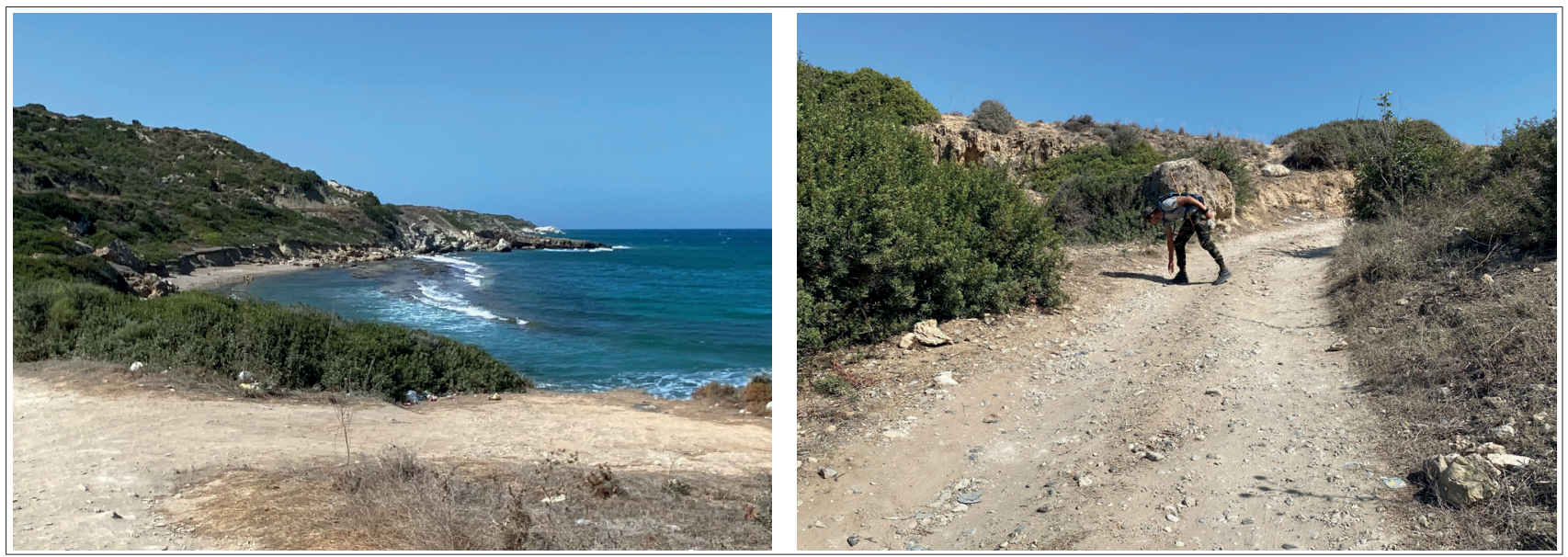

Figure 7. The area where the transported deposits of Vasilia-Mosphilia are observed. / Vasilia-Mosphilia'nın taşınmış birikimlerinin gözlemlendiği alan.

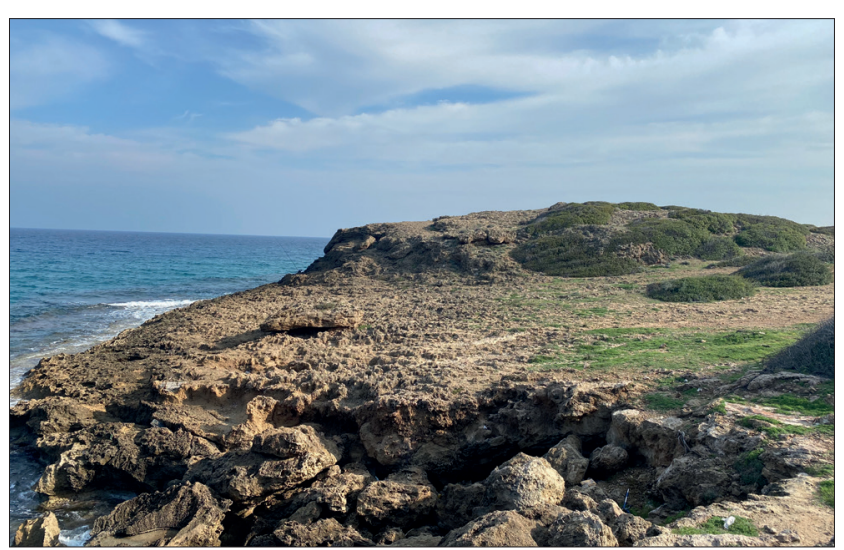

Figure 8. Pleistocene sandstones from Vasilia-Mosphilia. / VasiliaMosphilia'daki Pleistosen taşlaşmış kumullar.

the Pleistocene epoch were quite variable (Shackleton et al., 1990; Mudelsee \& Stattegger, 1994; Raymo, 1992; Barbante et al., 2010; Lisiecki, 2005; Imbrie et al., 1984; Caruso et al., 2011: 122-123; Berger et al., 2016; Bintanja et al., 2005). Besides, it is also stated that sea levels fall by -120 to -140 meters, especially during periods when glaciers cover up much area on land (Pillans et al., 1998: Table 1; Rovere et al., 2016: Fig.3e; Fig.2.4.). Glaio-eustatic adjustment is quite variable in this period (Lambeck \& Purcell, 2005: 1970-1972). Glaciers appear to be the leading cause of transgression and regression because glacial and interglacial periods ice-sheet, cover more or less surface in the lithosphere. (Creveling et al., 2017: 199-205; Dutton \& Lambeck, 2012: 217; Chiocci, 2017: 41-44; Rovere et al., 2016: 222-224: MurrayWallace \& Woodroffe, 2014: 2-3; Fairbanks, 1989).

\section{Mode I Artefacts From Vasilia-Mosphilia And Orga- Kourvelia: The Choppers And Chopping Tools}

Chopper and Chopping-tool, or its general definition Pebble Tools, are the oldest standard tools ever knapped by the genus Homo (Leakey, 1951: 34). The pebble tools are characteristic of Oldowan Industry defined by
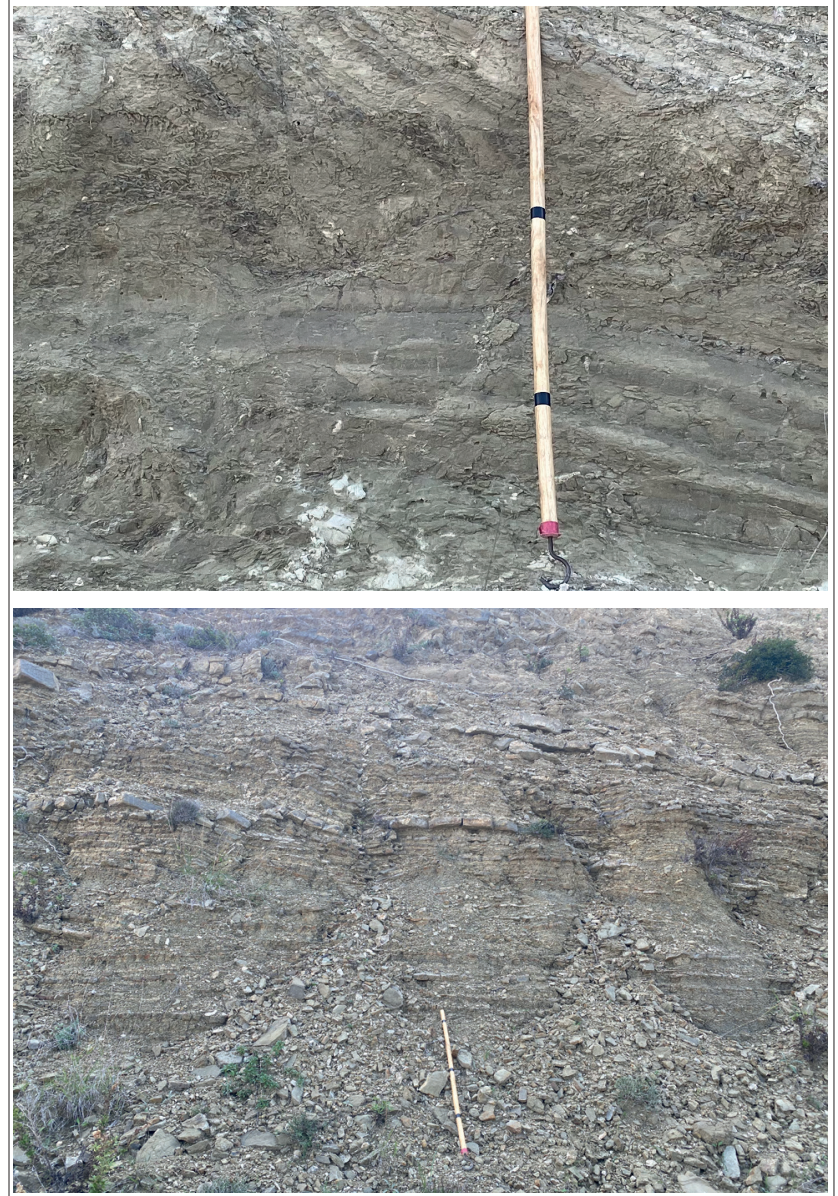

Figure 9. Section of marine terraces of Vasilia-Mosphilia. / VasiliaMosphilia'nın deniz teraslarının kesiti.

Leakey; however, Clark (1969: 31) made this industry easier to identify and classify in every region of the world by adapting it to a more general definition title of Mode I (Clark, 1977). Recently, Shea (2013b) made an important revision on Clark's Mode classification and suggested a framework as Mode A to I. According to Shea chopper and chopping-tool are defined under the title of Mode-C. The primary purpose is to sharpen the 
edge of unmodified raw material suitable for knapping. Generally, pebble stone or flintstone is preferred as raw material. If the raw material knapped from unifacially, it was classified as a chopper; if it was knapped from bifacially, it was classified as a chopping tool. These two terms were first used by Movius (1943: 351; 1948: 349$350)$.

Although pebble tool technology seems quite simple, it constitutes the most challenging group to define in Paleolithic studies. This situation could be considered primarily for the artefacts collected from the surface rather than in situ deposits. The raw materials that are broken by being dragged naturally and exposed to various external factors could be misleading. Therefore, which artefacts do not reflect a regular knapping process and have a single removal not included in the article's material. In addition, if removals do not exhibit main features of conchoidal fracture such as negative of the bulb, percussion wave or flake scars were also eliminated from the chipped stone assemblage. In line with these criteria, 13 pebble tools collected from the VasiliaMosphilia and Orga-Kourvelia are studied.

Many studies and methods in the literature classify choppers and chopping tools into subtypes (Alimen \& Chavaillon 1962: 5-6; Biberson, 1961: 417-428; Leakey, 1966; Hervieu, 1969; Collina-Girard, 1975). In particular, Dinçer's (2018) study on the "Thrace Finds" is up-todate and seems to be the most systematic and useful method in this regard. Dinçer states which edges of the artefacts were modified and their relationship with each other taken as the basis for creating different subtypes of Tekirdağ chopper and chopping tools (Dinçer, 2018: 39 ). However, it was preferred to classify only the main types as the chopper and chopping tools without dividing them into subtypes in our study. This preference is due to the small amount of material obtained as a result of the survey. In the future, if more extensive research is carried out in the region, focusing on the Paleolithic Age, the number of pebble tools will increase. Thus, as a result of a detailed techno-typological study, sub-type classification can be created more accurately.

In the general view of the chipped stone assemblages, it is observed that there is the predominant use of pebble stone. Three of the artefacts are made from flint, one is dolomite limestone, and the other nine are pebble stone. During the research, it was determined that the region is prosperous in terms of raw material resources. In particular, the geological deposits in which chert and radiolarite type rocks formed were clearly revealed with the sections opened as a result of road works. It is quite possible to observe that these rocks on the marine terraces started from the coastal line and rose to the south towards

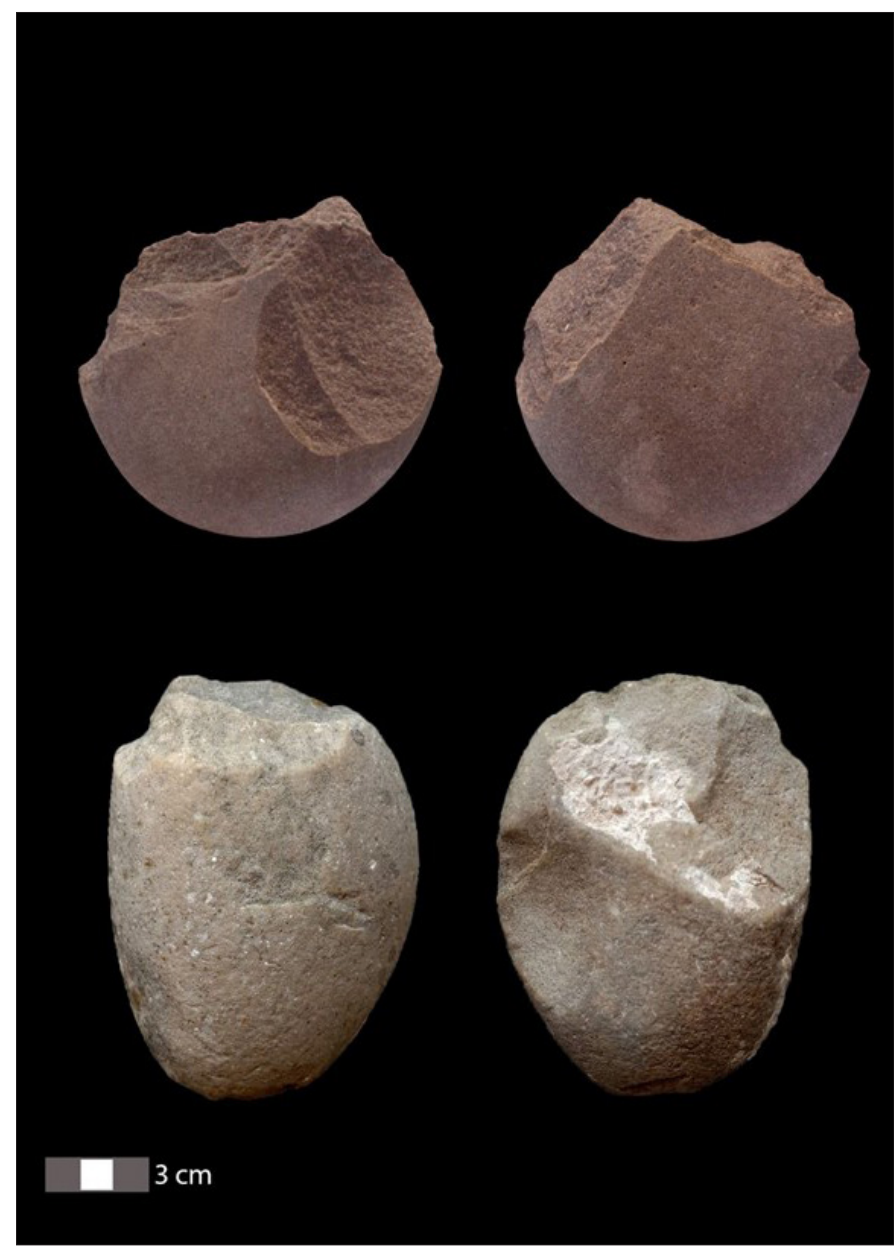

Figure 10. The chopping tools from Orga-Kourvelia. / OrgaKourvelia Kıyıcıları.

the mountain range. Apart from this, pebble stone, which is the most frequently used raw materials in our surface collection, are generally found in the valleys opening towards the sea and on the coastal plains.

In total, 13 pebble tools, consisting of nine choppers and four chopping tools, reflect morphologically and technologically different characteristics according to the two different regions in which they were found. The two chopping tools found at the Orga-Kourvelia (Figure 10) site show that they are larger than the samples found from Vasilia-Moshpilia. In addition, these two materials are very typical and reflect a carefully knapping and shaping process. One of the artefacts is made from reddish-brown coloured pebble stone and the other is made from grey, fine-grained dolomite limestone. In the chopping tool made of pebble stone, the retouches are concentrated on both the dorsal and ventral face of the material at the distal end and also extend the medial part with a few long removals (Figure 11.2). The retouches on the material have a semi-abrupt flaking angle and provide a convex shape to the distal part and a nose-like tip protruding forward. It was determined that breaks occurred on the 


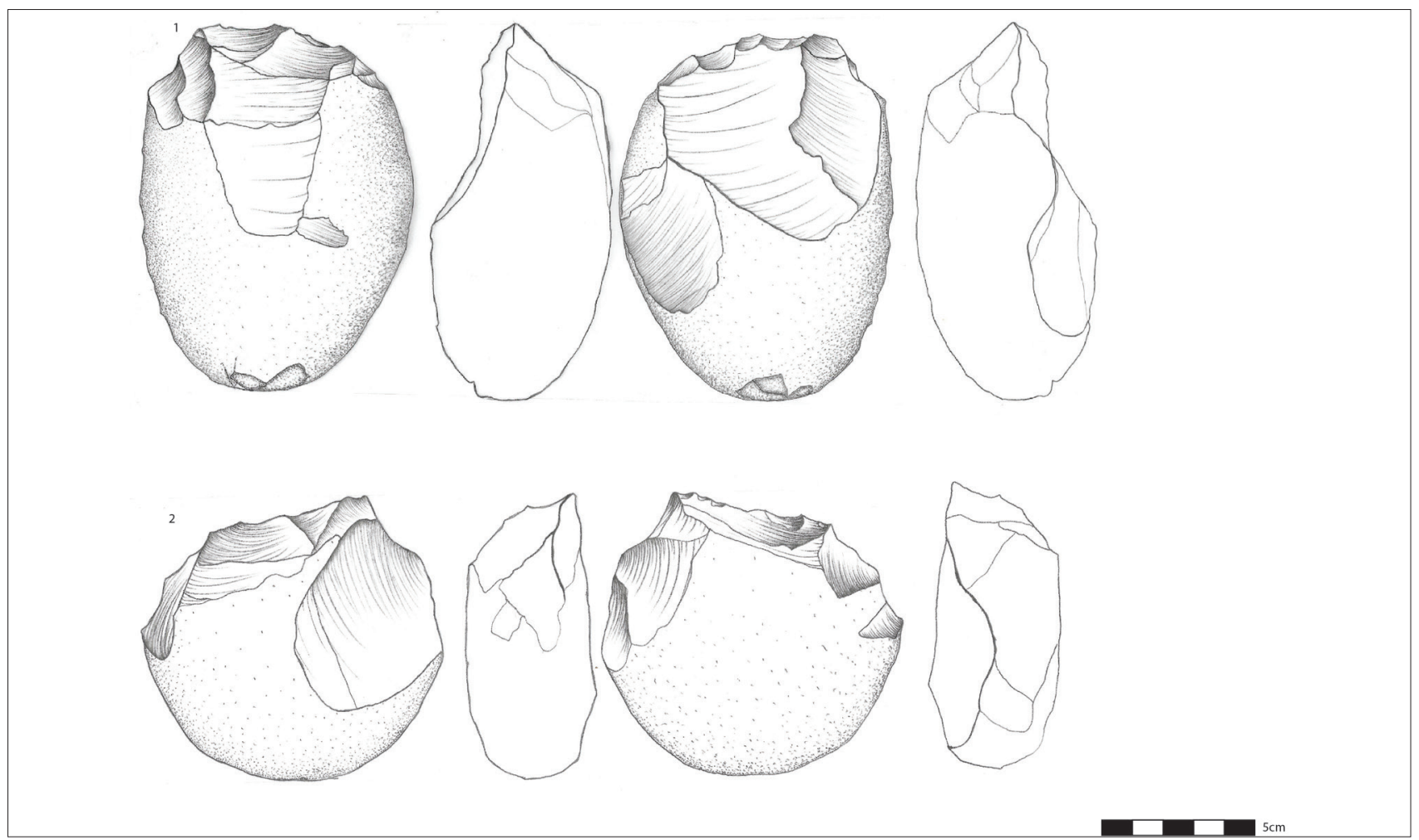

Figure. 11. The chopping tools from Orga-Kourvelia (Drawn by M. Özerenler). / Orga-Kourvelia Kıyıcıların çizimleri (M. Özerenler tarafindan çizildi).

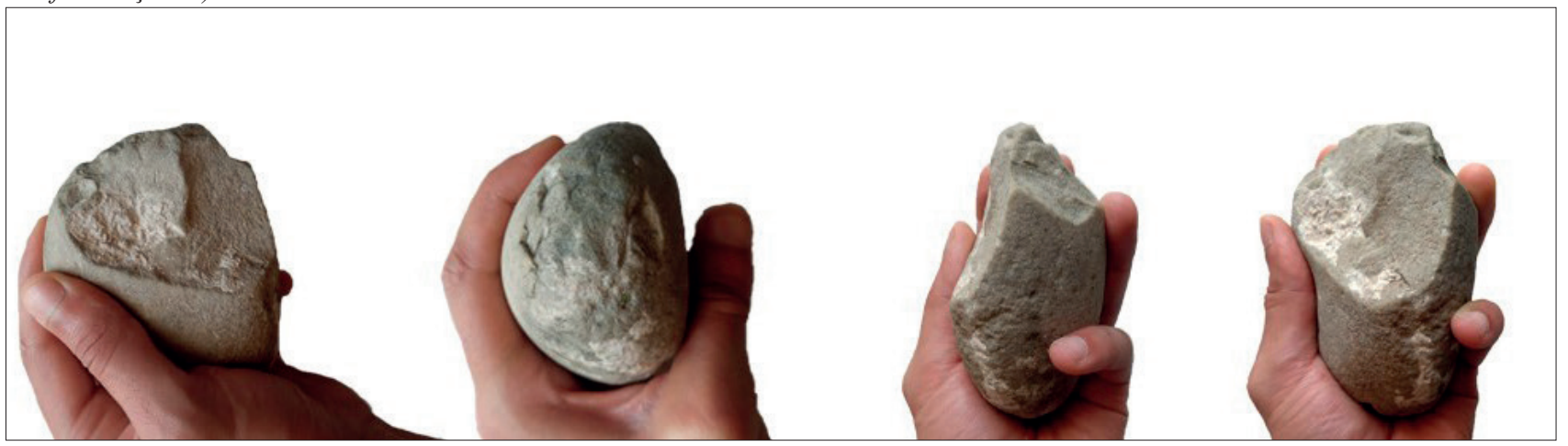

Figure 12. Photo of chopping tool showing the fit of the piece in the palm from Orga Kourvelia. / Orga Kourvelia'dan aletin avuç içine uygunluğunu gösteren klyıcının fotoğrafları.

retouched edge due to use and partially blunt. It can be seen that the other Chopping tool obtained from OrgaKourvelia has more elliptical morphology (Figure 11.1). In addition, the piece has been given a very ergonomic form with invasive removal on the lower face. The material fits well when it is placed in the palm from the unretouched proximal part (Figure 12). Suitability provides an essential advantage during use. When the section of the retouched edge of the dolomite limestone artefact is examined, it is visible that semi-abrupt retouches were used. Although the retouches on both faces are concentrated at the distal end, the lower face removals are more invasive than the upper face. In this example, unlike the other, there are crushes and breaks due to use in the unretouched proximal end (Figure 12). This feature may give important clues about the function of the material. For example, it is possible to associate the sharp retouched edge with cutting, shredding; while the unretouched edge refers to uses such as crushing and grinding or as a hammerstone. However, this macroscopically suggested proposal needs to be verified by use-wear analysis.

Ten of the eleven pebble tools from Vasilia-Mosphilia evaluated as chopper and one as chopping-tool (Figure 13, 14). Compared to the Orga-Kourvelia finds, the assemblages obtained here stand out smaller in size and illustrate that chert and radiolarite type rocks are also preferred as raw materials. The various sizes of raw materials probably compels knappers to apply different techniques in tool-making. For example, the retouches on the Vasilia-Moshpilia choppers and chopping tools 


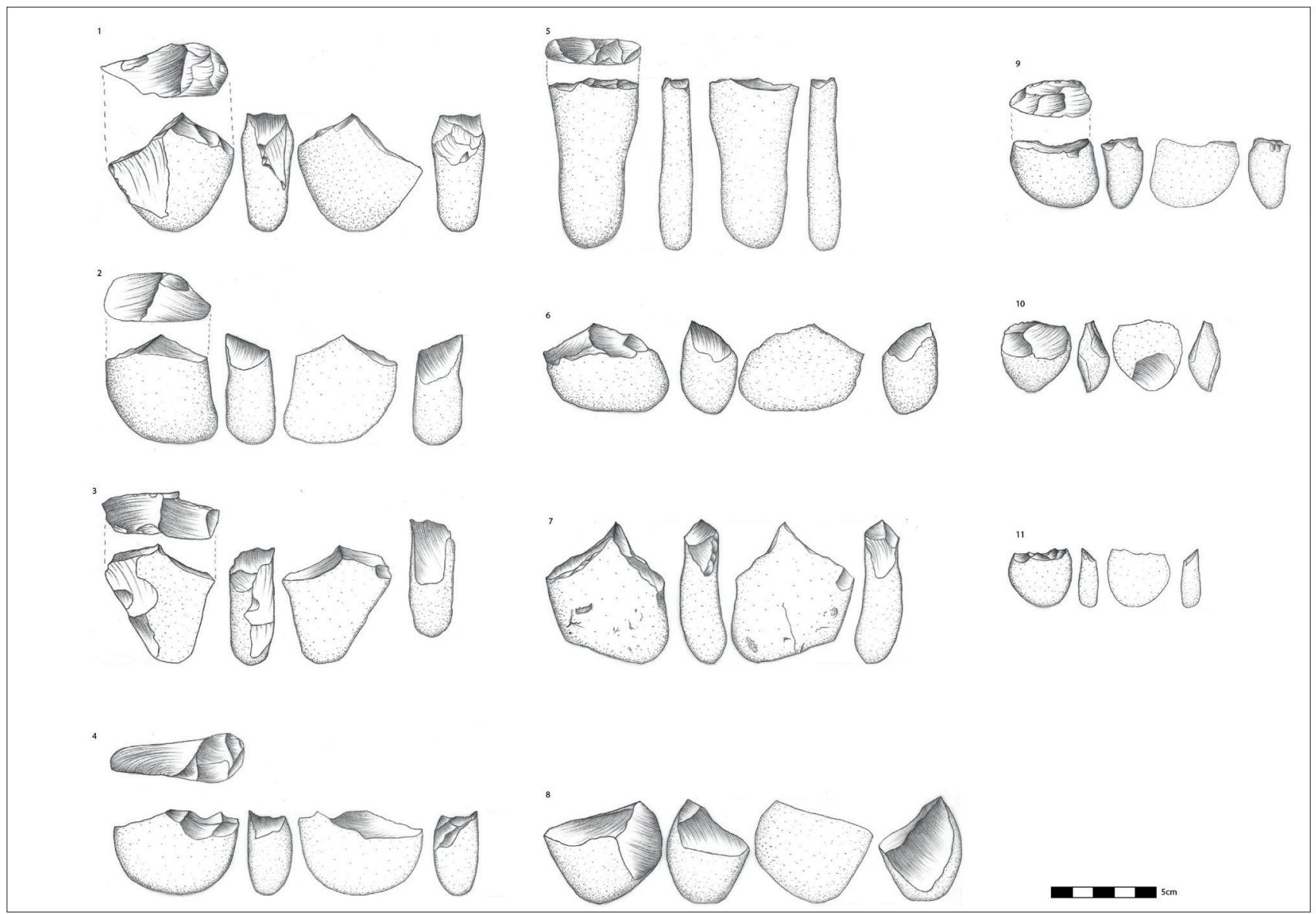

Figure 13. The chopping tools and choppers from Vasilia-Mosphilia.(Drawn by M. Özerenler). / Vasilia-Mosphilia Klyıcı ve Satırlarının çizimi (M. Özerenler tarafindan çizildi).

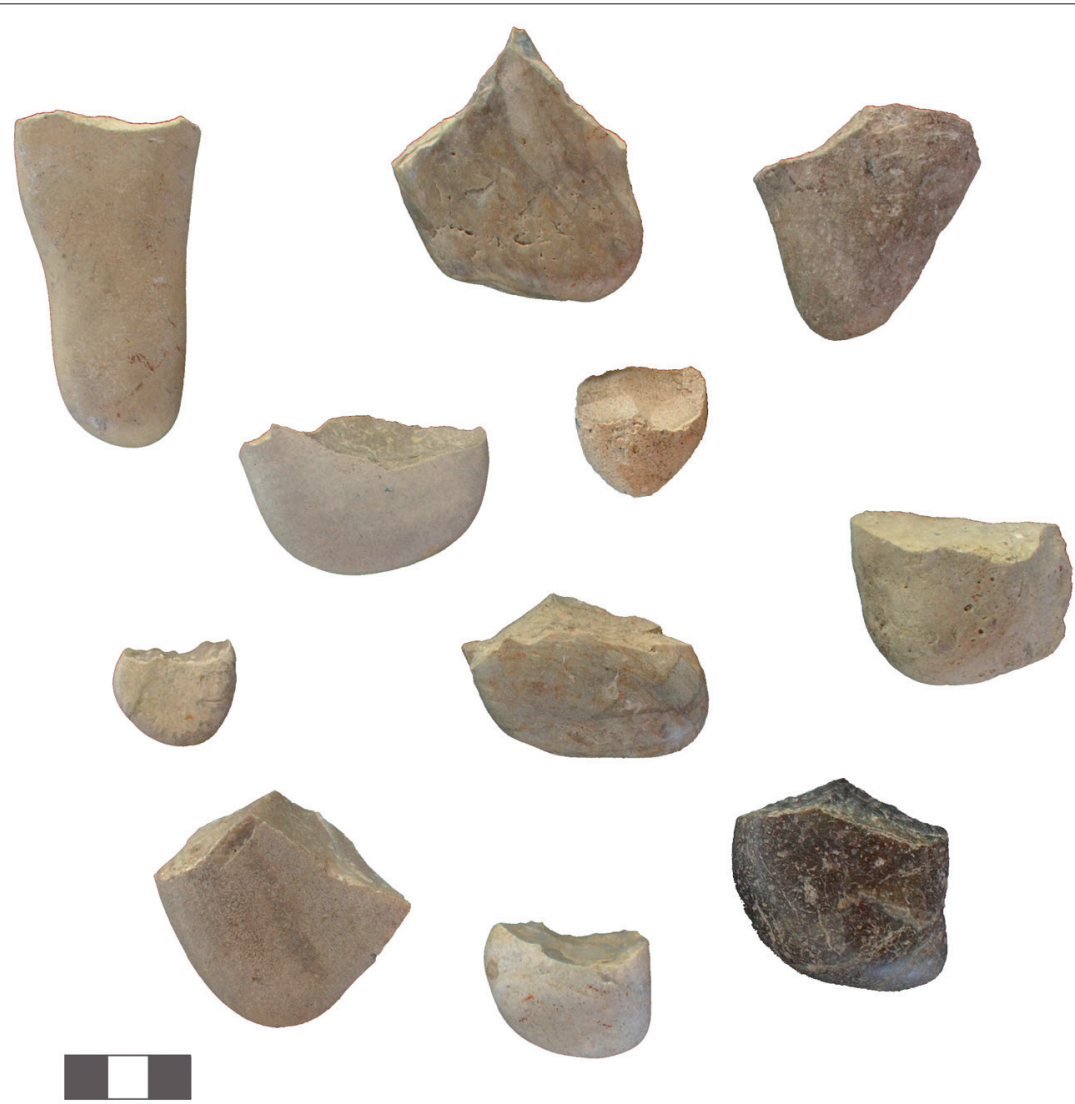

Figure 14. The chopping tools and choppers from Vasilia-Mosphilia. / Vasilia-Mosphilia Kıyıcı ve Satırları 
extended shortly on the blank, and abrupt retouches used sometimes. In the example classified as a chopping tool, a long and flat pebble stone is chosen as the blank (Figure 13.5). One of the short edges of this chopping tool has a bifacial and abrupt retouch. While the dorsal face has regular and short retouches, in contrast, a single and partially longer removal is taken on the ventral face. In the Vasilia-Moshpilia, ten examples of the choppers have more oval shape and smaller raw materials. Similar to the reddish-brown chopping-tool collected from Orga-Kourvelia (Figure 10), Vasilia-Moshpilia choppers contain a nose-like protruding tip on the retouched edge (Figure 13.1, 13.2, 13.6, 13.7). Apart from these, abrupt retouched pebble tools with a blunt edge observed in the collection (Figure 13.3, 13.5, 13.9) and three materials can be identified as mini-choppers because of their size (Figure 13. 9, 10, 11).

\section{CONCLUSION AND DISCUSSION}

In this article, a total of 13 chopper and chopping tools have been evaluated, which could be referred to the Lower/Middle Paleolithic period. Two different sites representing Pebble Tool technology, Orga-Kourvelia and Vasilia-Mosphilia, were discovered. The number of pebble tools collected from Vasilia-Mosphilia is more than the ones that were collected from Orga-Kourvelia. In the assemblages, rounded pebble stones and rarely radiolarite, chert type sedimentary rocks are mostly preferred as raw materials. When looking at the choice of blank, it's obvious that they are not reflecting any knapping process; all blanks consist of unmodified raw material. No flake was preferred as a blank for pebble tools. All in all, pebble tools are divided into two main types as chopper and chopping-tool; besides, pebble tools knapped from uniface, defined as choppers in the collection, are more dominant than chopping-tools knapped from biface.

There is no dating study for these chipped stone assemblages presented as a surface collection, however, considering the techno-typology of the material group, it could be argued that they may belong to at least the technology of the Lower/Middle Paleolithic chipped stone production. Unfortunately, there is no excavation or site to show stratigraphy of the Pleistocene in situ deposit, in other words, there is no Paleolithic excavation which we can compare our finds. Another factor that should be emphasized is the geographical and geological characteristics of the island. Cyprus is a bio-geographically isolated island, and because of this isolation, insular dwarfism can be observed obviously on the Pleistocene fauna; for instance, Elephas Cypriotes and Phanourius Minitus, are the unique examples for dwarfism (Hadjisterkotis, 2012; Simmons, 1988). Considering the strong influence of the geography of the island on the fauna, it should not be unusual for the Paleolithic people who lived in Cyprus to adapt to this environment not only biologically but also culturally. Thus, it is possible to ask this question: May "Cyprus Paleolithic Cultures" reflect different chronology and technological patterns than the Levant and Anatolia regions? This view could be falsified or developed by the excavation and comprehensive investigation of the Paleolithic Age in Cyprus. Therefore, rather than attributing a specific date range to the material group, it is correct to evaluate assemblages technotypologically and indicate which cultural phase they may belong to for now.

Although the material group does not allow us to carry out a detailed techno-typological study in terms of quantity, making a comparison of our finds with similar material groups in nearby geographies (Figure 15) based on the existing typological and morphological features will allow us to interpret the data of our study in a more reliable way. The comparison aims to identify similar assemblages in the surrounding region. In this context, rather than minor similarities, it has been tried to emphasize the major resemblance between the material groups. Two significant similarities were determined.

The first of these comes from the Lower Paleolithic localities, which were detected as a result of the research carried out by Ozhereliev et al., (2019) in the Euphrates basin. The area is called Şambayat and is located in the Göksu Stream valley, reflecting important results in Paleolithic studies; five different terraces are identified and dated geologically in different periods. According to this study, "terrace IV is correlated with the Olduvai subchron and adjacent parts of the Gelasian and Calabrian (Ozhereliev et al., 2019: 77)", so we have been observed interesting similarities between the pebble tools recovered from Şambayat IVa and our findings. The researchers classified the three pebble tools from IVa as "pointed chopper". Even though the chopper's terms were preferred to be used by researchers for these three materials, they actually typologically reflect chopping-tools features. This property has already been mentioned in the article by stressing that the pointed choppers were worked as bifacially (Ozhereliev et al., 2019: 77). The material from Orga-Kourvelia which is made on reddish-brown coloured pebble stone (See. Figure 11.2) and four of the Vasilia-Mosphilia pebble tools (See. Figure 13.1, $13.2,13.6,13.7)$ are quite similar to the Şambayat IVa "pointed choppers" (See. Ozhereliev et al., 2019, Figure. 6).

The second important similarity that should be mentioned comes from the results of the Kocasu Basin 
research, which have been investigated by Berkay Dinçer (Dinçer, 2014). Dinçer has identified three artefacts as mini or micro chopper which were found in the Görükle location. As Considering Dinçer's definition of "Those are very small pebbles $(2-4 \mathrm{~cm})$ that have small scraper kind of retouch on the edge (Dinçer, 2014: 41)", it should be emphasized that the two samples we obtained from Vasilia-Mosphilia (See. Figure 13.9, 13.11) are very similar to those found in Görükle. In addition, another artefact could be defined as a mini chopper but differs in terms of retouching type. In this sample, the retouches are represented by a few long removals rather than being continuous retouches as in scrapers (See. Figure 13.10).
It is known that Cyprus started to form approximately 85-90 Ma ago and is an oceanic island, which has never been connected to the mainland (Hadjisterkotis, 2012). In this regard, it is remarkable that Pebble Tool technology, the earliest examples recovered in the African continent, is seen on an isolated island such as Cyprus. In the literature, the question of LowerMiddle Paleolithic hominins crossing the sea from the mainland to the Mediterranean islands in the Middle and Late Pleistocene is still current and forms the basis of considerable debate. (Gaffney, 2020). Although data from Mediterranean islands mostly point to the Middle and Late Pleistocene, chipped stone finds collected from Plakias in Crete, Ayios Pavlos-Fetifes in Gavdos, Nea

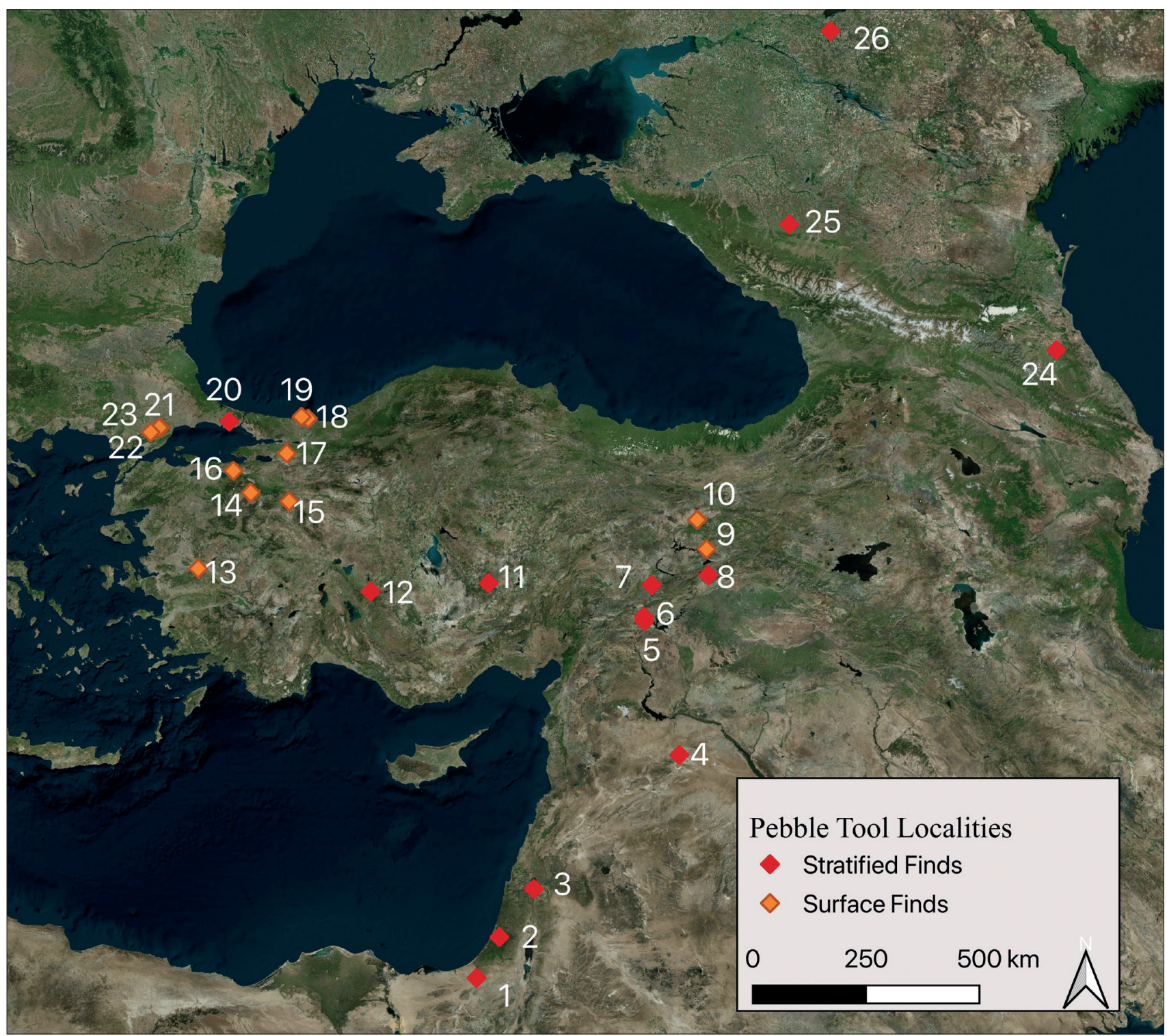

Figure 15: Pebble Tool Localities at neighbouring regions (1- Bizat Ruhama, 2-Revadim, 3- Ubedia, 4- Ain al Fil, 5- Bostancik, 6Şambayat, 7- Eski Malatya, 8- Kovancilar, 9- Pınarlar, 10- Taht Sirtları, 11- Kaletepe Deresi 3, 12- Dursunlu, 13- Bozyer, 14- Belentepe, 15- Kuzfindık, 16- Görükle, 17- Sakarya 5, 18- Sakarya 8, 19- Sakarya 6, 20- Yarımburgaz, 21- Yatak, 22- Balıtepe, 23- Kuştepe, 24Mukhai, 25- Dmanisi, 26- Ainikab 1). / Çevre bölgelerdeki Paleolitik lokaliteler (1-Bizat Ruhama, 2-Revadim, 3- Ubedia, 4- Ain al Fil, 5-Bostancı, 6- Şambayat, 7- Eski Malatya, 8- Kovancilar, 9- Pinarlar, 10- Taht Sirtlarl, 11-Kaletepe Deresi 3, 12-Dursunlu, 13- Bozyer, 14- Belentepe, 15- Kuzfindik, 16- Görükle, 17- Sakarya 5, 18- Sakarya 8, 19-Sakarya 6, 20- Yarımburgaz, 21 - Yatak, 22- Balttepe, 23Kuştepe, 24-Mukhai, 25- Dmanisi, 26-Ainikab 1). 
Skala in Kefalonia revealed that hominins crossed the sea barrier in the Lower Paleolithic period earlier than presumed (See. Strasser et al., 2010: 179-180, Fig. 132135; Mortensen, 2008; Runnels et al., 2014; Kopaka \& Matzanas, 2009; Papoulia, 2016: 6). In line with the Early Paleolithic data obtained from the Morphou Bay Prehistoric Survey, Pebble Tool technology in Cyprus supports the idea that crossing the sea of hominins could go back further. However, it is not reliable to refer to the Early Paleolithic lifestyle or cultural model on the island in the light of the data collected from the archaeological survey.

Nevertheless, tools produced with Pebble Tool technology found in the northwest of Cyprus were collected from two different sites. However, both areas differ in terms of their geographical features; OrgaKourvelia is in a high-altitude and rocky area, while Vasilia-Mosphilia is located on the beach, slightly above sea level. The artefacts reflect Pebble Tool technology, whereas collected from the surface are very close to Middle Paleolithic locality discovered during this survey have encouraged the research team to believe that the materials were transported by external factors; or the pebble tools produced within the context of Middle Paleolithic technology. We cannot assume that the materials were used as secondary raw material sources by the Middle Paleolithic knappers because there is no evidence to indicate different patina on the Vasilia-Mospihilia choppers and chopping tools. In addition, Vasilia-Mosphilia is open to environmental factors, and the existence of deposits accumulated by rivers around it supports this idea. On the contrary, the Orga-Kourvelia site, together with its mountainous location, which safeguarded the natural environment and geological structure, has characteristics that could be described as a rock shelter. For this reason, OrgaKourvelia is a site with the potential of a Paleolithic excavation in the future. In addition, considering the geological characteristics of the region, it is highly probable that the assemblages collected in VasiliaMosphilia on the coast might have been transported from high regions such as Orga-Kourvelia. Studies indicate that the Pleistocene marine terraces on the northern slopes of the Kyrenia Mountains are dated to earlier periods of Pleistocene as they rise from the coast and towards the mountainous region (Palamakumbura \& Robertson, 2016: 63, fig. 13). For this reason, probably, the in-situ Lower Paleolithic site in the northern side of the Kyrenia range should mainly be explored in mountainous regions. Although some of the material studied within the article is not in-situ, this does not change the idea that there is Pebble Tool technology in Cyprus. Current research is insufficient to assess whether the visits mentioned above, to the island were colonization or a one-off, random visit. However, more data is needed to understand even if the Lower Paleolithic Culture in Cyprus developed on the island by interaction from neighbouring cultural regions such as the Levant and Anatolia or locally.

\section{ACKNOWLEDGEMENT}

We would like to thank Eylem Özdoğan and Müge Şevketoğlu for their efforts and guidance in the realization of the survey. We pay tribute to the recently lost researcher, Carole McCartney, for her valuable comments and guidance on the material. In addition, we would like to express our appreciation to the local office staff, Mehmet Şöföroğlu, who contributed significantly to the accomplishment of the research. We also thank Ali Yılmaz for sharing the aerial photographs used in the article with us and allowing them to be published. Finally, we are grateful to Nadire Oyman, Necla Sütçüoğluları, Özkan Ibrahim and Sergen Irmak who proofread the paper. The authors confirm that the data supporting the findings of this study are available within the article and its supplementary materials. 


\section{BIBLIOGRAPHY}

ALIMEN, M. H. / J. CHAVAILLON, 1962.

"Position stratigraphique et évolution de la Pebble Culture au Sahara nord-occidental". In: G. Mortelmans and J. Nenquin (eds), Actes du IVe Congrès Panafricain de Préhistoire et de L'Etude du Quaternaire, Vol. III, 3-26. Tervuren: Musée royal de l'Afrique centrale.

AMMERMAN, A.J. 2020.

"Cyprus: The Submerged Final Palaeolithic of Aspros Dive Site C.” In: Bailey G., Galanidou N., Peeters H., Jöns H., Mennenga M. (eds) The Archaeology of Europe's Drowned Landscapes. Coastal Research Library, vol 35. Springer, Cham. https://doi.org/10.1007/978-3030-37367-2_22.

BARBANTE, C. / FISCHER, H. / MASSON-DELMONTE, V. / WAELBROECK, C. / WOLF, W. E. 2010. "Climate of the last million years: new insights from EPICA and other records". Quaternary Science Reviews, 29, 1-7. doi:10.1016/j.quascirev.2009.11.025.

BARSKY, D. 2009.

"An Overview of Some African and Eurasian Oldowan Sites: Evaluation of Hominin Cognition Levels, Technological Advancement and Adaptive Skills", in E. Hovers, \& D. R. Braun (Eds), Interdisciplinary Approaches to the Oldowan, (s. 39-48). Dordrecht, The Netherlands: Springer.

BAR-YOSEF, O. / BELFER-COHEN, A. 2001.

"From Africa to Eurasia - early dispersals". Quaternary International, 75, p. 19-28.

BASIRAN, A. / EREK, M. C. 2016.

"The Prehistoric Cultures in the Turkish Republic of Northern Cyprus". Society for American Archaeology 81 th Annual Meeting in Orlando, Florida,.https://www.saa. org/annual-meeting/programs/program-archives https:// www.academia.edu/27972133/The_Prehistoric_Cultures_in_the_Turkish_Republic_of_Northern_Cyprus

BENJaMIN, J. / ROVERE, A. / FONTANA, A. / FURLANI, S. / VACCHI, M. / INGLIS, H. R. / GALILI, F. / ANTONIOLI, F. / SIVAN, D. / MIKO, S. / MOURTZAS, N. / FELIJA, I. / MEREDITH-WILLIAMS, M. / GOODMAN-TCHHERNOV, B. / KOLAITI, E. / ANZIDEI, M. / GEHRELS. 2017.

"Late Quaternary sea-level changes and early human societies in the central and eastern Mediterranean $\mathrm{Ba}$ sin: An interdisciplinary review". Quaternary International, 449, 29-57. doi:10.1016/j.quaint.2017.06.025.

BERGER, A., ET AL. 2016.

"Interglacials of the last 800,000 years". Reviews of Geophysics, 54, 1-58. doi:10.1002/2015RG000482.
BIBERSON, P. 1961.

Le Paléolithique inférieur du Maroc atlantique. Rabat: Publications du Service des Antiquités du Maroc.

BINTANJA, R. / WA, R. S. / Oerlemans, J. 2005.

"Modelled atmospheric temperatures and global sea levels over the past million years". Nature, 437, 125128. doi:10.1038/nature03975.

BRAUN, R. D. / HOVERS, E. 2009.

"Introduction: Current Issues in Oldowan Research", in eds E. Hovers \& D. R. Braun, Interdisciplinary Approaches to the Oldowan, (1-14), Dordrecht, The Netherlands: Springer.

CARBONELL, E. / BERMUDEZ de CASTRO, J. / PARES, J., ET AL. 2008.

"The first hominin of Europe". Nature (452,), 465-469

CARBONELL, E. / SALA, R. D. / CELIBERTI, V. 2009.

"From Homogeneity to Multiplicity: A New Approach to the Study of Archaic Stone Tools". in E. Hovers, \& D. R. Braun (Eds), Interdisciplinary Approaches to the Oldowan (s. 25-38). Dordrecht, The Netherlands: Springer.

CARUSO, A. / COSENTINO, C. / PIERRE, C. / SULLI, A. 2011.

"Sea-level changes during the last 41,000 years in the outer shelf of the southern Tyrrhenian Sea: Evidence from benthic foraminifera and seismostratigraphic analysis". Quaternary International, 232(1-2), 122131. doi:10.1016/j.quaint.2010.07.034.

CAVAZZA, W. / WEZEL, F. C. 2003.

"The Mediterranean region-a geological primer". Episodes, 26(3), 160-168.

CHIOCCI, L. F. / CASALBORE, D. / MARRA, F. / ANTONIOLI, F. / ROMAGNOLI, C. 2017.

"Relative Sea Level Rise, Palaeotopographyand Transgression Velocity on the Continental Shelf". in J. H. Geoffrey N. Bailey (Eds), Under the Sea: Archaeology and Palaeolandscapes of the Continental Shelf (s. 39-52). Gewerbestrasse 11, 6330 Cham, Switzerland: Springer.

CLARK, G. 1969.

World Prehistory:A New Outline (2nd ed.). Cambridge University Press.

COLLINA-GIRARD, J. 1975.

Les industries archaïques sur galets des terrasses quaternaires de la plaine du Roussillon (P.O. France). Marseille: Laboratoire de Paléontologie humaine et Préhistoire, Université de Provence (Saint-Charles). 
CREVELING, R. J. / MITROVICA, X. J. / CLARK, U. P. / WAELBROECK, C. 2017.

"Predicted bounds on peak global mean sea level during marine isotope stages $5 a$ and $5 c$ ". Quaternary Science Reviews, 163, 193-208. doi:10.1016/j.quascirev.2017.03.003.

ÇINER, A. / ŞENGÖR, A. / KHELIF, N. 2019.

"Mediterranean Geoscience Reviews: a Mediterranean perspective”. Mediterranean Geoscience Reviews, 1, 1-4. doi:https://doi.org/10.1007/s42990-019-0001-6.

DİNÇER, B. / TÜRKCAN, A. U. 2011.

"Frigya'da Illk Insanin İzleri: Kuzfindlk Vadisi Paleolitik Dönem Bulgularl (Eskişehir)”. Arkeoloji ve Sanat, 137: 45-52.

DİNÇER, B. 2014.

"Paleolithic of Kocasu Basin (NW Anatolia)". Arkeoloji'de Bölgesel Çalışmalar Sempozyum Bildirisi, YAS 4, p.23-49.

DINÇER, B. 2016a.

"Kuzeybatı Anadolu'da Paleolitik Araștırmalar". Türk Eskiçağ Bilimleri Enstitüsü Haberler, 41: 50-54.

DINÇER, B. 2016b.

"The Lower Paleolithic in Turkey: Anatolia and Hominin Dispersals out of Africa Running head: Lower Paleolithic in Turkey". in K. Harvati, \& M. Roksandic (Eds), Paleoanthropology of the Balkans and Anatolia: Human Evolution and its Context (s. 213-228). Dordrecht, The Netherlands: Springer.

DİNÇER, B. 2018.

"Alt Paleolitik Satır ve Kiyıcıların Tekno-Tipolojisi: Tekirdăg Buluntuları". in A. Baysal (Eds), Anadolu Arkeolojisinde: Teori, Metot, Pratik (s. 31-68). İstanbul: Ege Yayınları.

DUTTON, A. / LAMBECK, K. 2012.

"Ice volume and sea level during the last interglacial". Science, 337, 216-219. doi:10.1126/science.1205749.

FAIRBANKS, R. G. 1989.

"A 17,000-year glacio-eustatic sea level record: influence of glacial melting rates on the Younger Dryas event and deep-ocean circulation". Nature, 342, 637642 .

GABUNIA, L. / VEKUA, A. / LORDKIPANIDZE, D. 2000.

"The Environmental Contexts of Early Human Occupation of Georgia (Transcaucasia)". Journal of Human Evolution, 38(6), 785-802.
GAFFNEY, D. 2020.

"Pleistocene Water Crossings and Adaptive Flexibility Within the Homo Genus". Journal of Archaeological Research. DOI10.1007/s10814-020-09149-7.

GALILI, E. / ŞEVKETOĞLU, M. / SALAMON, A. / ZVIELY, D. / MIENIS, K. H. / ROSEN, B. / MOSHKOVITZ, S. 2015.

"Late Quaternary beach deposits and archaeological relicts on the coasts of Cyprus, and the possible implications of sea-level changes and tectonics on the early populations". in J. B. Harff (Eds), Geology and Archaeology: Submerged Landscapes of the Continental Shelf (s. 179-278). London: The Geological Society of London. doi:10.1144/SP411.10.

HADJISTERKOTIS, E. 2012.

"The Arrival of Elephants on the Island of Cyprus and Their Subsequent Accumulation in Fossil Sites". In M. Aranovich, \& O. Dufrense (Eds), Elephants: Ecology, Behavior and Conservation. New York: Nova Science Publishers.

HANKE, W. 2015.

"Historical Overview of Paleoanthropological Research". In W. Hanke \& I. Tattersall (Eds.), Handbook of Paleoanthropology (pp. 3-95). Springer. 10.1007/9783-642-39979-4 1.

HARMAND, S. ET AL. 2015.

"3.3-million-year-old stone tools from Lomekwi 3, West Turkana, Kenya”. Nature, 310-315. doi:10.1038/nature14464.

HERVIEU, J. 1969.

"Les industries a galets amenagés du haut bassin de la Benoue (Cameroun)". Bulletin de l'Association Sénégalaise pour l'étude du quaternaire de l'ouest Africain 22: 24-34.

İLKSEVEN, S. 2021.

Kıbrıs Fiziki Coğrafya. Okman Printing.

IMBRIE, J. / HAYS, J. D. / MARTINSON, D.G. / MCINTYRE, A. / MIX, A. C. / MORLEY, J. J. / PISIAS, N. G. / PRELL, W. L. / SHACKLETON, N. J. 1984.

"The Orbital Theory of Pleistocene Climate: Support from a Revised Chronology of the Marine d18O Record". in A. B. al. (Eds), Milankovitch and Climate. Part 1 (s. 269-305). Dordrecht, Netherlands: D. Reidel Publishing Company.

KEY, A. J. / ROBERTS, D. L. / JARIC, I. 2021.

"Statistical inference of earlier origins for the first flaked stone". J Hum Evol. doi: 10.1016/j.jhevol.2021.102976. 
KINNARD, T. C. / ROBERTSON, A. H. / MORRIS, A. 2011.

"Timing of uplift of the Troodos Massif (Cyprus) constrained by sedimentary and magnetic polarity evidence". Journal of the Geological Society, London, 457-470. doi:10.1144/0016-76492009-150.

KLEIN, R. G. 2008.

"Out of Africa and the Evolution of Human Behavior".

Evolutionary Anthropology, 17, 267-281.

KNAPP, A. B. 2010.

"Cyprus's Earliest Prehistory: Seafarers, Foragers and

Settlers”. Journal of World Prehistory, 23, 79-120.

KOPAKA, K. / MATZANAS, C. 2009.

"Palaeolithic industries from the island of Gavdos,near neighbour to Crete in Greece". Antiquity Project Gallery, 83(321).

KUTOĞLU, S. 2010.

Kuzey Kıbrıs Türk Cumhuriyeti'nin Jeomorfolojik ve Uygulamalı Jeomorfolojik Etüdü. Yayınlanmamış Doktora Tezi. İstanbul: İstanbul Üniversitesi Sosyal Bilimler Enstitüsü.

LAMBECK, K. / PURCELL, A. 2005.

"Sea-level change in the Mediterranean Sea since the LGM: modelpredictions for tectonically stable areas". Quaternary Science Reviews, 24, 1969-1988. doi:10.1016/j.quascirev.2004.06.025.

LEAKEY, L. S. B. 1951.

Olduvai Gorge: A Report on the Evolution of the Hand-Axe Culture in beds I-V. Cambridge University Press.

LEAKEY, M. D. 1966.

"A Review of the Oldowan Culture from Olduvai Gorge, Tanzania". Nature, 210: 462-466.

LISIECKI, L. E. 2005.

"A Pliocene-Pleistocene stack of 57 globally distributed benthic $\delta 180$ records". Paleoceanography, 20, 1-17. doi:10.1029/2004PA001071.

LORDKIPANIDZE, D. / JASHASHVILI, T. / VEKUA, A. / de LEON, M. S. P. / ZOLLIKOFER, C. P. E. / RIGHTMIRE, G. P. / ROOK, L. 2007.

"Postcranial evidence from early Homo from Dmanisi, Georgia". Nature, 449(7160), 305-310.

LORT, J. M. 1977.

"Geophisycs of the Mediterranean". in A. E. Nairn, W. H. Kane, \& F. G. Stehli (Eds), The Ocean Basins and Marigins: Volume 4A The Eastern Mediterranean. New York: Plenum Press.
MATHER, A. 2009.

"Tectonic Setting and Landscape Development". In J. Woodward (Eds), The Physical Geography of the Mediterranean, (s. 5-32). New York: Oxford University Press.

MGELADZE, A. / LORDKIPANIDZE, D. / MONCEL, M.-H. / CHAGELISHVILI, R. / NIORADZE, M. / NIORADZE, G. 2011.

"Hominin occupations at the Dmanisi site, Georgia, Southern Caucasus: Raw materials and technical behaviours of Europe's first hominins". Journal of Human Evolution, 571-596. doi:10.1016/j.jhevol.2010.10.008.

MORTENSEN, P. 2008.

"Lower to Middle Palaeolithic artefacts from Loutró on the south coast of Crete". Antiquity Project Gallery, 82(317).

MOVIUS, H.L. 1943.

"The Stone Age of Burma". Transactions of the American Philosophical Society 32: 341-394.- 1944. Early man and Pleistocene stratigraphy in southern and eastern Asia. Papers of the Peabody Museum of American Archaeology and Ethnology, Harvard University 19(3).

MUDELSEE, M. / STATTEGGER, K. 1994.

"Plio-/Pleistocene Climate Modeling Based on OxygenIsotope Time Series from Deep-Sea Sediment Cores:The Grassberger-Procaccia Algorithm and Chaotic Climate Systems". Mathematical Geology, 26(7), 799-815. doi:10.1007/BF02083118.

MURRAY-WALLACE, C. V. / WOODROFFE, C. D. 2014.

Quaternary Sea Level Changes: A Global Perspective. New York: Cambridge University Press.

OZHERELYEV, V. D. / TRIFONOV, G. V. / ÇELIK, H. / TRIKHUNKOV, I. Ya. / FROLOV, D. P. / SIMAKOVA, N. A. 2019.

"Early Palaeolithic evidence from the Euphrates River basin, Eastern Turkey". Quaternary International, 509, p. 73-86.

PALAMAKUMBURA, R. N. / ROBERTSON, A. H. 2016. "Pleistocene terrace deposition related to tectonically controlled surface uplift: An example of the Kyrenia Range lineament in the northern part of Cyprus". Sedimentary Geology, 339, 46-67.

PALAMAKUMBURA, R. N. / ROBERTSON, A. H. / KINNAIRD, T. C. / CALSTEREN, P. V. / KROON, D. / TAIT, J. A. 2016.

"Quantitative dating of Pleistocene deposits of the Kyrenia Range, northern Cyprus: implications for timing, rates of uplift and driving mechanisms". Journal of the Geological Society. doi::10.1144/jgs2015-130. 
PAPOULIA, C. 2016.

"Seaward dispersals to the NE Mediterranean islands in the Pleistocene. The lithic evidence in retrospect". Quaternary International, 1-24. doi:10.1016/j.quaint.2016.02.019.

PILLANS, B. / CHAPPELL, J. / NAISH, T. R. 1998. "A review of the Milankovitch climatic beat: template for Plio-Pleistocene sea-level changes and sequence stratigraphy”. Sedimentary Geology, 122, 5-21.

RAYMO, M. E. 1992.

"Global Climate Change: A Three Million Year Perspective". in W. E. Kukla G.J. (Eds), Start of a Glacial. NATO ASI Series (Series I: Global Environmental Change) (s. 207-223). Berlin, Heidelberg: Springer. doi:10.1007/978-3-642-76954-2_15.

RELETHFORD, J. 2008.

"Genetic evidence and the modern human origins debate”. Heredity, 100, 555-563.

ROBERTSON, A. / XENOPHONTOS, C. 1993.

"Development of concepts concerning the Troodos ophiolite and adjacent units in Cyprus". Geological Society, 76(1), 85-119. doi:10.1144/gsl. sp.1993.076.01.05.

ROVERE, A. / PAOLO STOCCHI, P. / MATTEO, V. 2016.

"Eustatic and relative sea level changes". Current Climate Change Rep, 2, 221-231. doi:10.1007/ s40641-016-0045-7.

RUNNELS, C. / MCCOY, F. / BAUSLAUGH, R. / MURRAY, P. 2014.

"Palaeolithic research at Mochlos, Crete: new evidence for Pleistocene maritime activity in the Aegean". Antiquity Project Gallery, 88(342).

SCERRİ, E. M. L. / CHIKI, L. / THOMAS, M. G. 2019.

"Beyond multiregional and simple out-of-Africa models of human evolution". Nature Ecology\&Evolution. 10.1038/s41559-019-0992-1.

SHACKLETON, J, N. / BERGER, A. / PELTIER, R, W. 1990.

"An Alternative Astronomical Calibration of the Lower Pleistocene Timescale Based on Odp Site". Transactions of the Royal Society of Edinburgh Earth Sciences, 81, 251-261. doi:10.1017/S0263593300020782.

SHEA, J. J. 2013a.

Stone Tool in the Paleolithic and Neolithic Near East A Guide. Cambridge University Press.
SHEA, J.J. 2013b.

"Lithic Modes A-I: A New Framework for Describing Global-Scale Variation in Stone Tool Technology Illustrated with Evidence from the East Mediterranean Levant". J Archaeol Method Theory 20, 151-186 https:// doi.org/10.1007/s10816-012-9128-5.

SIMMONS, H. A. 1988.

"Extinct Pygmy Hippopotamus and Early Man in Cyprus". Nature, 333.

STOCKTON, E. D. 1968.

"Pre-Neolithic Remains at Kyrenia, Cyprus?" Report of the Department of Antiquities Cyprus, 16-19.

STRASSER, T. F. / PANAGOPOULOU, E. / RUNNELS, C. N. / MURRAY, P. M. / THOMPSON, N. / KARKANAS, P. / McCOY, F. W. / WEGMANN, K. W. 2010.

"Stone Age seafaring in the Mediterranean: Evidence from the Plakias region for Lower Palaeolithic and Mesolithic habitation of Crete". Hesperia, 145-190.

STRASSER, T. F. / RUNNELS, C. / VITA-FINZI, C. 2016.

"A possible Palaeolithic hand axe from Cyprus". Antiquity Project Gallery, 90(350). Retrieved March 13, 2021, from https://www.antiquity.ac.uk/projgall/strasser350.

TEMPLETON, A. R. 2007.

"Genetics and recent human evolution". Evolution, 61, 1507-1519.

VILLMOARE, B. / KIMbEL, W. H. / SEYOUm, C. / COMPISANo, C. J. / DI MAGGIO, E. N. / ROWAN, J. / BRAUN, D. R. / ARROWSMITH, J. R. / REED, K. E. 2015.

"Early Homo at 2.8 Ma from Ledi-Geraru, Afar, Ethiopia”. Science, 347(6228), 1352-1355.

VITA-FINZI, C. 1973.

"Palaeolithic finds from Cyprus?". Proceedings of the Prehistoric Society, 39, 453-454. 10.1017/ S0079497X00011749.

WOLPOFF, M. H. / HAWKS, J. / CASPARI, R. 2000. "Multiregional, Not Multiple Origins". American Journal of Physical Anthropology, 112, 129-136. 
